\title{
Evidence and analysis of 2012 Greenland records from spaceborne observations, a regional climate model and reanalysis data
}

\author{
M. Tedesco ${ }^{1}$, X. Fettweis ${ }^{2}$, T. Mote ${ }^{3}$, J. Wahr ${ }^{4}$, P. Alexander ${ }^{1,5}$, J. E. Box ${ }^{6}$, and B. Wouters ${ }^{4,7}$ \\ ${ }^{1}$ The City College of New York, The City University of New York, New York, NY 10031, USA \\ ${ }^{2}$ University of Liege, Liege, Belgium \\ ${ }^{3}$ University of Georgia, Athens, GA 30602, USA \\ ${ }^{4}$ Department of Physics and Cooperative Institute for Research in Environmental Sciences, University of Colorado, \\ Boulder, CO 80309, USA \\ ${ }^{5}$ The Graduate Center of the City University of New York, New York, NY, USA \\ ${ }^{6}$ The Ohio State University, Columbus, OH, USA \\ ${ }^{7}$ School of Geographical Sciences, University of Bristol, Bristol, UK
}

Correspondence to: M. Tedesco (mtedesco@sci.ccny.cuny.edu)

Received: 24 October 2012 - Published in The Cryosphere Discuss.: 30 November 2012

Revised: 23 February 2013 - Accepted: 9 March 2013 - Published: 4 April 2013

\begin{abstract}
A combined analysis of remote sensing observations, regional climate model (RCM) outputs and reanalysis data over the Greenland ice sheet provides evidence that multiple records were set during summer 2012. Melt extent was the largest in the satellite era (extending up to $\sim 97 \%$ of the ice sheet) and melting lasted up to $\sim 2$ months longer than the 1979-2011 mean. Model results indicate that near surface temperature was $\sim 3$ standard deviations $(\sigma)$ above the 1958 2011 mean, while surface mass balance (SMB) was $\sim 3 \sigma$ below the mean and runoff was $3.9 \sigma$ above the mean over the same period. Albedo, exposure of bare ice and surface mass balance also set new records, as did the total mass balance with summer and annual mass changes of, respectively, $-627 \mathrm{Gt}$ and $-574 \mathrm{Gt}, 2 \sigma$ below the 2003-2012 mean. We identify persistent anticyclonic conditions over Greenland associated with anomalies in the North Atlantic Oscillation (NAO), changes in surface conditions (e.g., albedo, surface temperature) and preconditioning of surface properties from recent extreme melting as major driving mechanisms for the 2012 records. Less positive if not increasingly negative SMB will likely occur should these characteristics persist.
\end{abstract}

\section{Introduction}

During the past decade, surface melting over the Greenland Ice Sheet (GrIS) has been increasing (e.g., Hanna et al., 2008; Fettweis et al., 2013a; Mote, 2007; Tedesco et al., 2008, 2011, Mernild et al., 2011), with results from regional climate models, in situ observations and satellite data revealing accelerating ice sheet mass loss (van den Broeke et al., 2009; Rignot et al., 2011). Melting is responsible for summer meltwater production over the GrIS, which ultimately translates into runoff to the surrounding ocean. Aside from the direct impact of increased runoff on the surface mass balance (SMB) of the GrIS, changes in the meltwater production affect supraglacial, englacial and subglacial processes. Persistent and enhanced melting can lead to reduced surface albedo (because of snow grain size metamorphism or bare ice exposure, for example) and, consequently, to increased absorbed solar radiation (which further enhances melting). The existence of supraglacial lakes, whose formation is driven by meltwater production, increases the ice ablation rate relative to that of bare ice at the surface (e.g., Tedesco et al., 2012a). Moreover, rates of meltwater production play a key role in modulating the opening and persistence of surface-tobedrock connections (e.g., hydro-fracturing; e.g., Weertman, 1973; van der Veen, 2007; Catania et al, 2008), which are associated with ice sheet velocity spatio-temporal gradients 
and, therefore, can impact the total GrIS mass balance. Given the complex and nonlinear nature of the mechanisms linking melting to other surface and sub-surface processes, it is crucial to adopt a multidisciplinary approach in which multiple tools are used to identify different aspects of extreme events and their drivers. This enables the limitations of any single method to be overcome, providing a more comprehensive understanding of the phenomenon under observation.

Here, we combine results obtained from the analysis of spaceborne remote sensing data, the outputs of a regional climate model (RCM) and reanalysis data to show evidence that multiple records were set during the summer of 2012 over the GrIS, and to investigate the driving mechanisms. In particular, for the summer of 2012, new records were set for melt extent and duration derived from passive microwave remote sensing (1979-2012), satellite-derived snow/ice surface temperature and albedo (2000-2012), RCM-derived surface mass balance, bare ice exposure, runoff and near-surface temperature (1958-2012), and total mass balance derived from gravimetric satellite measurements (2002-2012). In many cases, the new records were exceeding the mean by values between 2 and 4 standard deviations. In Sect. 2, we describe the data and methods employed; in Sect. 3 we discuss the records associated with each data set examined; lastly, in Sect. 4, we investigate the drivers of the records; conclusions follow in Sect. 5.

\section{Methods and data}

\subsection{Melt extent and duration from passive microwave data}

Wet snow can be mapped at large spatial scales and high temporal resolution from spaceborne measurements collected in the microwave region of the electromagnetic spectrum. As the liquid water content (LWC) within the snowpack increases, so does the absorption as a consequence of the increase of the imaginary part of snow permittivity. In the case of passive microwave sensors, this has the consequence of suddenly and considerably increasing the recorded microwave brightness temperature $\left(T_{\mathrm{b}}\right)$ (e.g., Tedesco, 2007). Microwave sensors can also detect sub-surface liquid water (with penetration depth ranging from a few centimeters to several meters in the case of dry snow and up to a few centimeters in the case of wet snow, depending on frequency and LWC), which can occur when the surface is frozen and, therefore, cannot be detected with thermal sensors.

We use data collected by the Scanning Multichannel Microwave Radiometer (SMMR) and by the Special Sensor Microwave Imager (SSM/I). SMMR was a five-frequency instrument on the Nimbus-7 satellite. It had dual-polarized, horizontal $(\mathrm{H})$ and vertical $(\mathrm{V})$, channels at 6.63, 10.69, 18.0, 21.0, and $37.0 \mathrm{GHz}$ (Gloersen et al., 1984). The first SSM/I sensor was launched aboard the DMSP F8 mission in 1987 (Hollinger et al., 1987). A series of SSM/I sensors on subsequent DMSP satellites has provided a continuous data stream since then. Sensors on the F-8, F-11, F-13, and F-17 platforms are used for the data used here. The SSM/I sensor has seven channels at four frequencies. The 19.4, 37.0 , and $85.5 \mathrm{GHz}$ frequencies are dual polarized $(\mathrm{H}$ and $\mathrm{V})$; the $22.2 \mathrm{GHz}$ frequency has only a single vertically polarized channel. For simplicity, the channels are sometimes denoted as simply $19 \mathrm{H}, 19 \mathrm{~V}, 22 \mathrm{~V}, 37 \mathrm{H}, 37 \mathrm{~V}, 85 \mathrm{~V}$ and $85 \mathrm{H}$. The SSM/I sensor was replaced by the Special Sensor Microwave Imager/Sounder (SSMIS) sensor with the launch of F-16 in 2003. The SSMIS sensor has the same 19.4, 22.2, and $37.0 \mathrm{GHz}$ channels of SSM/I. However, the $85.5 \mathrm{GHz}$ channels on SSM/I are replaced with $91.0 \mathrm{GHz}$ channels on SSMIS. This does not affect the melt detection, as this frequency is not used in the algorithms considered here.

The National Snow and Ice Data Center (NSIDC) processes and combines swath brightness temperature data from Remote Sensing Systems, Inc. (RSS) (http://www. ssmi.com). The NSIDC distributes SMMR, SSM/I and SSMIS as gridded daily products, distributed in a polar stereographic projection and the Equal Area Earth Scalable (EASE) projection with a $25 \mathrm{~km}$ spatial resolution. Near-realtime DMSP SSMIS Daily Polar Gridded Brightness Temperatures (http://nsidc.org/data) and EASE-Grid Brightness Temperatures (http://nsidc.org/data/docs/daac/nsidc) are also available through NSIDC and are used here for the analysis reported in the following for the 2012 season. Though nearreal-time data did not go through the same processing as fully processed data, the difference between the two data sets is generally small (on the order of $1-2 \mathrm{~K}$ at most, but below that on average based on a comparison performed by the authors using data from previous years over Greenland). Because of the strong impact of LWC on recorded brightness temperatures (e.g., increase of the order of tens of $\mathrm{K}$, up to $100 \mathrm{~K}$ in some cases, when moving from dry to wet snow conditions; e.g., Tedesco, 2007), we assume that the use of near-real-time brightness temperatures does not impact the results discussed in the following for the 2012 melting season.

Changes in melt duration and extent over the Greenland and Antarctic ice sheets have been mapped using the seasonal change in emissivity and thresholds computed through the aid of electromagnetic models (Mote and Anderson, 1995; Mote, 2007; Tedesco, 2009), the frequency dependence of emissivity, such as the cross polarized gradient ratio (XPGR; e.g., Abdalati and Steffen, 1997; Steffen et al., 2004), the diurnal change in emissivity (e.g., Tedesco, 2007) and fixed threshold coefficients (e.g., Zwally and Fiegles, 1994). Here, we use the algorithms reported by Mote and Anderson (1995) and Tedesco (2009), as they are based on a similar concept (e.g., when the LWC within the snowpack is assumed to exceed a certain threshold). The algorithm of Mote and Anderson (1995) is a dynamic threshold algorithm (DTA) based on a simple microwave emission model, which is used to simulate $37 \mathrm{GHz}$ horizontally 
polarized brightness temperatures associated with $1 \%$ liquid water content across the Greenland ice sheet (Mote, 2007). The other approach is based on Tedesco (2009) and assumes a fixed value of LWC to compute the brightness temperature threshold (still from an electromagnetic model) above which melt is assumed to be occurring. This approach is conceptually similar to the one originally proposed by Zwally and Fiegles (1994), producing coefficients that are similar to those produced in that approach but that are spatially and temporally dynamically computed.

\subsection{MODIS albedo and surface temperature}

The Moderate Resolution Imaging Spectroradiometer (MODIS) on board the Terra and Aqua satellites (http://modis.gsfc.nasa.gov/) records data in 36 spectral bands between 0.4 and $14.4 \mu \mathrm{m}$. MODIS thermal infrared observations allow estimates of land surface temperature (LST) under cloud-free conditions at a $1 \mathrm{~km}$ horizontal spatial resolution. In particular, the MODIS MOD11A1 data product (http://www.icess.ucsb.edu/modis/) makes use of daily averaged LST retrievals from swath data using bands $31(11 \mu \mathrm{m})$ and $32(12 \mu \mathrm{m})$ (Wan et al., 2002; Wan, 2008). The root mean square error (RMSE) of the MOD11A1 product with respect to independent in situ observations has been estimated to be $1{ }^{\circ} \mathrm{C}$ (Wan, 2008), with higher RMS errors $\left(>1{ }^{\circ} \mathrm{C}\right.$ ) found over Greenland (Hall et al., 2008, b; Koenig and Hall, 2010).

Surface albedo retrievals from the NASA Terra platform MODIS sensor beginning 5 March 2000 are available from the NSIDC (Hall et al., 2011). The daily MOD10A1 product is used in this study instead of other available products, such as the MODIS MOD43 (http://modis.gsfc.nasa.gov/data/dataprod/) or MCD43 8-day (http://www-modis.bu.edu/brdf/userguide/intro.html) products, in order to increase temporal resolution. After collection, the data are interpolated to a $5 \mathrm{~km}$ EASE grid. Stroeve et al. (2006) showed that the MOD10A1 product captures the albedo seasonal cycle, but exhibits more temporal variability than recorded by in situ observations. A dominant component of this assessed error might be the failure of the MODIS data product to completely remove cloud effects. Another problem might be the presence of spuriously low values, for example below 0.4 in the accumulation area, where albedo is not observed by pyranometers at the surface to drop below 0.7. In this study, we follow the approach reported by Box et al. (2012), in which 11 day running statistics are here used to identify and reject values that exceed 2 standard deviations from an 11 day average. To prevent rejecting potentially valid cases, data within 0.04 of the median are not rejected. June-August (JJA or summer) seasonal averages are then generated from monthly averages of the daily filtered and smoothed data. Only data from the Terra MODIS instrument is used in this study, to reduce computational burdens and given an Aqua MODIS instrument near-infrared (channel 6) failure (Hall et al., 2008a) that reduces the cloud detection capability.

\subsection{The MAR regional climate model}

MAR is a 3-D coupled atmosphere-land surface model that predicts the evolution of the coupled land-atmosphere system (subject to land-atmosphere feedbacks) in response to radiative forcing from the sun, and known or projected atmospheric forcing applied at the model's lateral boundaries. The atmospheric portion of MAR is coupled to the 1-D surfacevegetation-atmosphere transfer scheme SISVAT (Soil Ice Snow Vegetation Atmosphere Transfer; Gallée and Schayes, 1994 and De Ridder and Gallée, 1998), which simulates surface properties and the exchange of mass and energy between the surface and the atmosphere. SISVAT incorporates an interactive snow model based on the CROCUS model (Brun et al., 1992), a 1-D layered energy and mass balance model of the snowpack capable of simulating up to 20 snow and ice layers. CROCUS is more sophisticated with respect to snow models used by most RCMs (e.g., Rae et al., 2012) in that it is a physically based model capable of simulating the evolution of snow properties, such as grain sizes and shapes, in response to energy and mass changes within the snowpack, and their influence on surface albedo. CROCUS also incorporates a water balance module that takes into account the refreezing of meltwater, a turbulence module, and a snow/ice discretization module (Brun et al., 1992).

MAR has been used to simulate long-term changes in the GrIS SMB and surface melt extent (Fettweis et al., 2005, 2011; Tedesco et al., 2008, 2011) using ERA-40 (19581978) and ERA-INTERIM reanalysis (1979-2012) (Dee et al., 2011) as forcing every 6 hours at the MAR lateral boundaries. Validation has been performed through comparison with ground measurements (e.g., Lefebre et al., 2003, 2005; Gallée et al., 2005), and satellite data (e.g., Fettweis et al., 2005, 2011; Tedesco et al., 2011). These studies have demonstrated the validity of the model for accurately simulating climate changes (Fettweis et al., 2013b; Franco et al., 2013) and capturing feedback mechanisms, including surface air temperatures, specific humidity, wind speed, surface albedo, melting, and radiative fluxes over Greenland.

Specifically, comparisons with weather station data from the Greenland Climate Network (GC-Net; Steffen et al., 1996) reveal that MAR captures annual surface temperatures within $\sim 1-2{ }^{\circ} \mathrm{C}$ (Fettweis et al., 2011; Box et al., 2012). The lack of available SMB measurements limits the degree to which model SMB estimates can be assessed. When compared with annual SMB measurements (1990-2008) at the GrIS ablation zone K-transect (van de Wal et al., 2012), MAR exhibits an RMSE of $24 \%$ of simulated SMB (the best of four models), but is less accurate (RMSE of $46 \%$ ) when compared with ice core estimates over the center of the ice sheet (Vernon et al., 2012). Another comparison with available ice core estimates suggests MAR overestimates SMB 
by $20-25 \%$ over the ice sheet accumulation zone (Rae et al., 2012). Despite limitations associated with a lack of available observations, these studies suggest that relative changes in SMB predicted by MAR and other models should be emphasized rather than the absolute value of SMB estimates, which is sufficient for the purposes of this study. Here, MAR is run at a $25 \mathrm{~km}$ resolution (though outputs can be used to estimate the SMB at higher resolution, e.g., Franco et al., 2012) with the specific model setup discussed by Fettweis (2007) and with adjustments to the albedo scheme as noted by Fettweis et al. (2011). Only the first $10 \mathrm{~m}$ of snow/ice are resolved in the snow model. Ice is added at the bottom of the snowpack if its height is lower than $8 \mathrm{~m}$ (Franco et al., 2013). The refreezing scheme is described in Reijmer et al. (2012). Initialization of the snow model follows Fettweis et al. (2005) and Lefebre et al. (2005), where further details can be found.

\subsection{GRACE}

The Gravity Recovery and Climate Experiment (GRACE) satellite mission has been providing monthly solutions for the earth's global gravity field since its launch in spring of 2002. These solutions can be used to determine time variations in the gravity field, which provide information on month-tomonth variations in the earth's mass distribution (e.g., Tapley et al., 2004; Wahr et al., 2004). Here, we use monthly GRACE gravity fields from April, 2002, through September, 2012, generated and made publicly available by the Center for Space Research (CSR) at the University of Texas (http://podaac.jpl.nasa.gov), to solve for temporal changes in the total mass of the Greenland ice sheet. CSR's Release 4 fields were used for months prior to March 2003, and Release 5 fields were used for all months thereafter. Each monthly field consists of a set of spherical harmonic geoid coefficients up to degree and order 60 . We replace the GRACE $\mathrm{C}_{20}$ coefficients with $\mathrm{C}_{20}$ coefficients inferred from satellite laser ranging (Cheng and Tapley, 2004), and we include degree-one coefficients computed as described by Swenson et al. (2007) (coefficients provided by S. Swenson). We use model results from A et al. (2013) to remove contributions from glacial isostatic adjustment (GIA): the earth's viscoelastic response to past ice mass variability. Those GIA results were computed for a compressible, spherically symmetric earth, and were based on the global ICE-5G model and VM2 viscosity profile of Peltier (2004).

We compute the temporal mean of the monthly fields and subtract that mean from each field, so that the residuals represent the monthly departures from the mean. We convolve each monthly residual field with a Greenland averaging kernel chosen to minimize the combined measurement error and signal leakage, as described by Velicogna and Wahr (2006), to obtain an estimate of Greenland mass per area in units of $\mathrm{cm}$ of water averaged over the ice sheet. Like any filtering process, this convolution has the potential of causing a loss of signal. To correct for this, we follow Velicogna and Wahr (2006) and determine a scaling factor by applying this analysis procedure to several simulated, but plausible, ice loss patterns. We multiply each monthly mass-per-area estimate by this scaling factor to obtain variations in the total mass of the ice sheet (in Gt) about its temporal average.

\section{Results}

\subsection{Surface temperature}

Figure 1a shows the map of 2012 JJA near-surface air temperature (3 m) anomalies (1958-2011 baseline) from MAR, indicating largely positive anomalies (up to $4-5^{\circ} \mathrm{C}$ ) over the entire GrIS. Surface temperature anomalies are extreme at high elevations, especially in the north and south regions, where melting lasted longer than previous years (see next section). Over the GrIS, anomalies at relatively low elevations closer to the coast are $\sim 0{ }^{\circ} \mathrm{C}$. This is a consequence of the fact that melting generally occurs there every year for most of the summer and, therefore, near-surface air temperature is already close to the melting point for most of the season. Figure $1 \mathrm{~b}$ shows the mean JJA LST estimated by MODIS averaged over the entire Greenland ice sheet for the period 2000-2012. The JJA ice-sheet-wide MODIS LST increased $3.4^{\circ} \mathrm{C}$ between years 2000 and 2012, from an average value of $\sim-9^{\circ} \mathrm{C}$ in 2000 to $-5.6^{\circ} \mathrm{C}$ in 2012 , with a linear fit suggesting an increase of $+2.1 \pm 0.7^{\circ} \mathrm{C}$ over the last $13 \mathrm{yr}$. The MAR model (respectively, ERA-INTERIM) suggests an increase of $+1.3(1.1)^{\circ} \mathrm{C}$ of the JJA near-surface temperature for the period 2000-2012. Knowing that observations were assimilated in ERA-INTERIM and that the trend of the near-surface temperatures should be higher than the surface temperature limited to $0^{\circ} \mathrm{C}$, this suggests that MODIS could overestimate the trends. This is likely a consequence of sensor changes in the MODIS-based time series (Box et al., 2012). Nevertheless, the 2012 JJA average GrIS near-surface temperature simulated by MAR was the warmest since 1958 , with an anomaly of $+2.6^{\circ} \mathrm{C}$ (i.e., 2.9 times the standard deviation over 1958-2011). Finally, some coastal weather stations recorded JJA 2012 as the warmest JJA period since the beginning of the observations (more than $100 \mathrm{yr}$ ) according to Hanna et al. (2013). We note that while MODIS provides estimates of the actual snow/ice surface temperature, the near-surface air temperature represents the air temperature at $3 \mathrm{~m}$ above the surface.

\subsection{Melting from passive microwave spaceborne data}

GrIS melting in 2012 set a new record, according to results obtained from spaceborne microwave data (Tedesco 2009; Mote and Anderson, 1995). Nearly the entire 2012 summer experienced above-normal melt extent across the ice sheet (Fig. 2a), with 79 of 92 days in JJA with melt extent greater than average. The only multiple-day periods with belowaverage melt extent occurred between 10-24 May and at the 

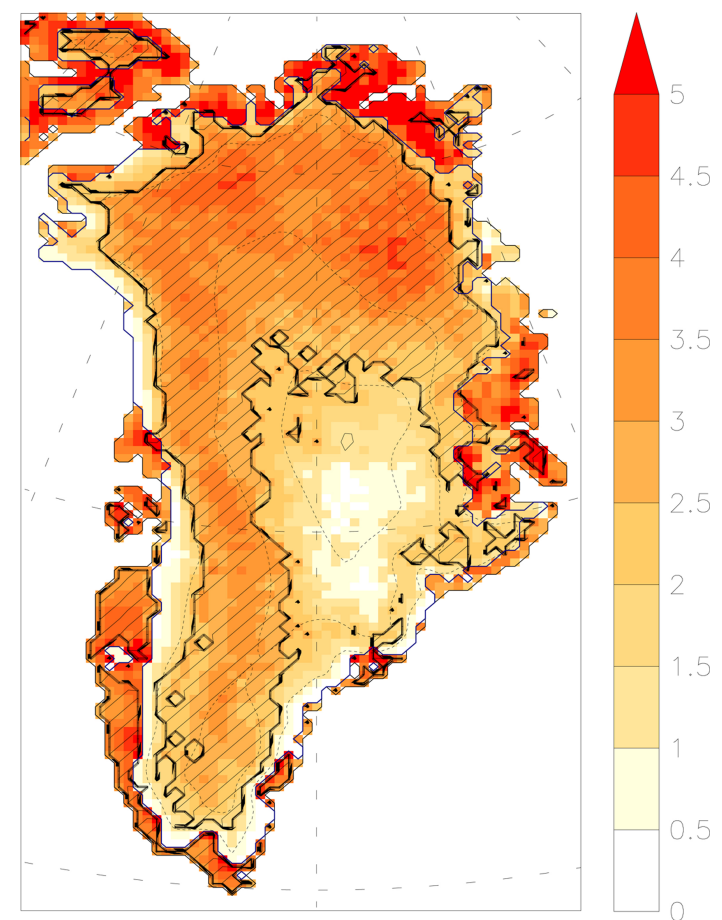

(a)2012 JJA surface temperature anomaly (K)

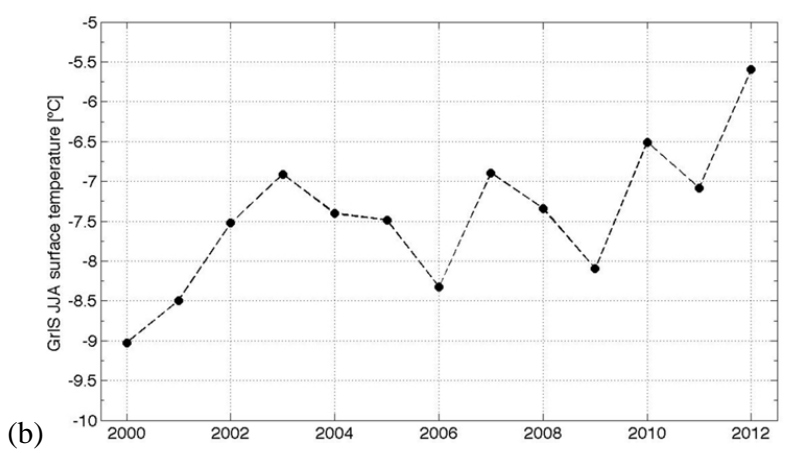

Fig. 1. (a) 2012 JJA surface temperature anomaly (1958-2011 baseline) simulated by MAR. Hatched areas indicate regions were the anomaly was above two standard deviations from the mean. (b) Annual JJA mean surface temperature from MODIS averaged over the entire Greenland ice sheet for the period 2000-2012.

end of August. Apart from a period around mid-June, more extensive melt than average persisted from 27 May through 22 July and throughout much of August 2012. The area covered by melting was larger in 2012 than for any other year in the microwave satellite era (1979-2012), and 2012 was the first year within the satellite era when nearly the entire ice sheet experienced melt (Fig. 2b, c). The melt extent on Greenland reached a one-day record during the period 11-12 July, when at least $97 \%$ of the ice sheet underwent melt (Nghiem et al., 2012). The Nghiem et al. (2012) work was based on multiple satellite products; the individual product following Mote and Anderson (1995) produced a maximum single-day melt extent of $90 \%$ on 11 July, com- (a)
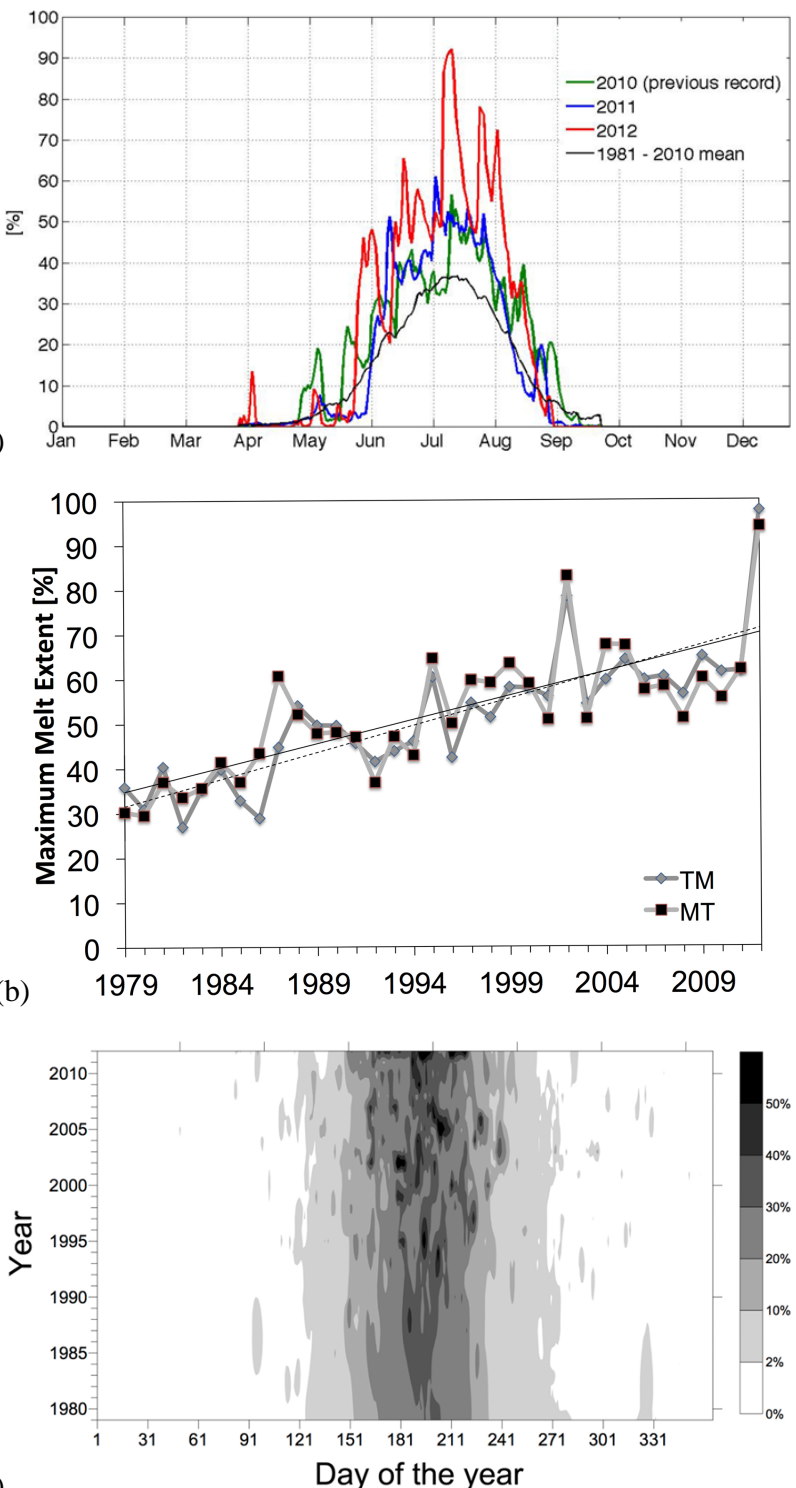

(c) Day of the year

Fig. 2. (a) Melt extent (as a percentage of the Greenland ice sheet) time series derived from spaceborne passive microwave observations using the algorithm in Tedesco (2009) in 2012 (red), in 2011 (blue), 2010 (green, being the previous record) and for the 1981-2010 mean (black). (b) Maximum melt extent for the period 1979-2012 using the algorithm in Mote and Anderson (1995), denoted as TM, and in Tedesco (2009), denoted as MT. (c) Daily simulated GrIS melt extent (in \% of the ice sheet area) from January through December for 1979 through 2012 from passive microwave based on the algorithm given in Mote and Anderson (1995).

pared to $23 \%$ on average for 11 July, and $>97 \%$ over the period of 11-13 July. The previous maximum melt extent was $77 \%$ on 28 June 2002, but three days in summer 2012 exceeded the 2002 maximum. The melt extent exceeded $60 \%$ of the ice sheet a total of 10 days in 2012 , compared to three days in 2002; only one other year (2005) had even a single day of melt extent exceeding $60 \%$ of the 


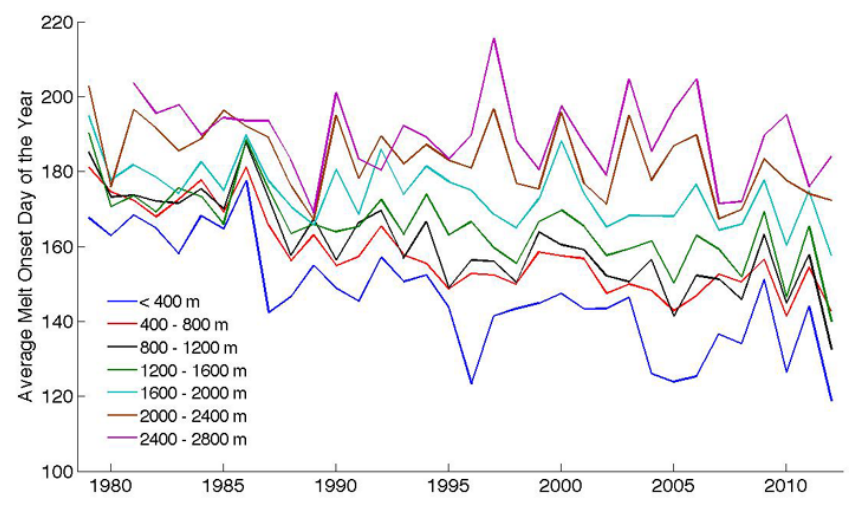

Fig. 3. Average melt onset date (day of year) by elevation bands from passive microwave data using the algorithm in Mote and Anderson (1995).

ice sheet. The updated 1979-2012 trend for melt extent is $22337 \pm 24 \mathrm{~km}^{2} \mathrm{yr}^{-1}\left(1.3 \% \mathrm{yr}^{-1}\right)$ following Mote and Anderson (1995) and $20325 \pm 22 \mathrm{~km}^{2} \mathrm{yr}^{-1}\left(1.19 \% \mathrm{yr}^{-1}\right)$ following Tedesco (2009).

In 2012, melting started more than two weeks earlier than average along large bands of the ice sheet below $1200 \mathrm{~m}$ a.s.l. An analysis updated through summer 2012 indicates that areas below $2400 \mathrm{~m}$ a.s.l. have experienced increasingly earlier melt onset dates since 1979, defined as the first day of the calendar year with melt, with the greatest changes occurring at lower elevations (Fig. 3, Table 1). According to results obtained using the algorithm of Mote and Anderson (1995), melt onset at the lowest elevations $(<400 \mathrm{~m}$ a.s.l.) has been occurring 11.59 days earlier per decade $(r=0.78, p<0.01)$. This implies that, on average, melting in 2012 started about one month earlier than it did $33 \mathrm{yr}$ ago. At higher elevations, as expected, the trend of the melt onset is smaller, with melting starting on average 2.65 days earlier per decade $(r=0.23, p=0.24)$ for areas above $2400 \mathrm{~m}$ and below $2800 \mathrm{~m}$ (areas above $2800 \mathrm{~m}$ are not considered here because they do not melt every year). As an example, a transect at $72^{\circ} \mathrm{N}$ in West Greenland had melt exceeding 60 days in JJA at elevations below $1700 \mathrm{~m}$ a.s.l., exceeding the 1981-2010 average by roughly 40 days between 1600 and $1800 \mathrm{~m}$ (Table 2). The regression coefficient of the melt onset trend expressed as a function of elevation is $0.0368 \pm 0.0004$ days $\mathrm{m}^{-1}$ decade $^{-1} \quad(r=0.97)$ using Mote and Anderson (1997) and $0.0363 \pm 0.0004$ days $^{-1}$ decade $^{-1}$ using Tedesco (2009). Before 2012 the trend of the melt onset regression coefficients was $0.0360 \pm 0.0004$ days $^{-1}$ decade $^{-1}$ using Mote and Anderson (1997) and $0.0359 \pm 0.004$ days $^{-1}$ decade $^{-1}$ using Tedesco (2009).
Table 1. Melt onset trend in days decade ${ }^{-1}$ for different elevation bands derived from passive microwave data using the approach by Mote and Anderson (1995).

\begin{tabular}{ll}
\hline Elevation band & Days decade $^{-1}$ \\
\hline$<400 \mathrm{~m}$ & $-11.59 \pm 0.015$ \\
$400-800 \mathrm{~m}$ & $-9.27 \pm 0.010$ \\
$800-1200 \mathrm{~m}$ & $-9.83 \pm 0.012$ \\
$1200-1600 \mathrm{~m}$ & $-7.31 \pm 0.012$ \\
$1600-2000 \mathrm{~m}$ & $-4.93 \pm 0.012$ \\
$2000-2400 \mathrm{~m}$ & $-4.49 \pm 0.015$ \\
$2400-2800 \mathrm{~m}$ & $-2.65 \pm 0.015$ \\
\hline
\end{tabular}

In 2012, melting lasted longer than average for the majority of the areas subject to melting (Fig. 4a, b), up to 30 days longer than the 1981-2010 average for large areas of West Greenland below $2400 \mathrm{~m}$ a.s.l. For areas in northwest Greenland between 1400 and $2000 \mathrm{~m}$ a.s.l., melting lasted up to two months longer than average. The cumulative melting index, MI (defined as the number of melting days times the area subject to melting), set a new record in 2012. Figure $4 \mathrm{c}$ shows the time series of the annual standardized melting index (SMI, the MI minus its mean and divided by the standard deviation) obtained using the results from the two passive microwave algorithms. The new SMI record was $\sim 2.5$ standard deviations above the 1981-2010 mean (represented by the 0 value on the y-axis in the SMI plot), while the previous record set in 2010 was $\sim 1.2$ standard deviations above the mean.

Because the use of microwave data does not allow one to estimate either LWC within the snowpack (or ice) or the amount of liquid water that refreezes after melting, it is difficult to translate the surface melting record detected by spaceborne microwave sensors into runoff and, ultimately, into surface mass balance. Moreover, to interpret the 2012 melting record in terms of surface mass balance, it is essential to know the mass that accumulated after the end of the previous melting season and to compute the net mass for the hydrological year (which here is defined starting on 1 September and ending on 31 August). Following this aim, the results of the regional climate model MAR are used here to complement those obtained from remote sensing and are reported in the following section.

\subsection{Surface mass balance}

The SMB simulated by MAR for the 2011-2012 hydrological year (from September 2011 through August 2012) is the lowest for the period 1958-2012 (Fig. 5a, $\sim-400 \mathrm{Gt} \mathrm{yr}^{-1}$ anomaly), setting a new record for modeled SMB. The 2012 SMB value is 3 standard deviations below the 1958-2011 mean, exceeding by $\sim 100 \mathrm{Gt} \mathrm{yr}^{-1}$ the previous record set in $2010\left(\sim-300 \mathrm{Gt} \mathrm{yr}^{-1}\right.$ anomaly, Fig. 5a). According to MAR, the 2012 SMB record is driven by the record melt 

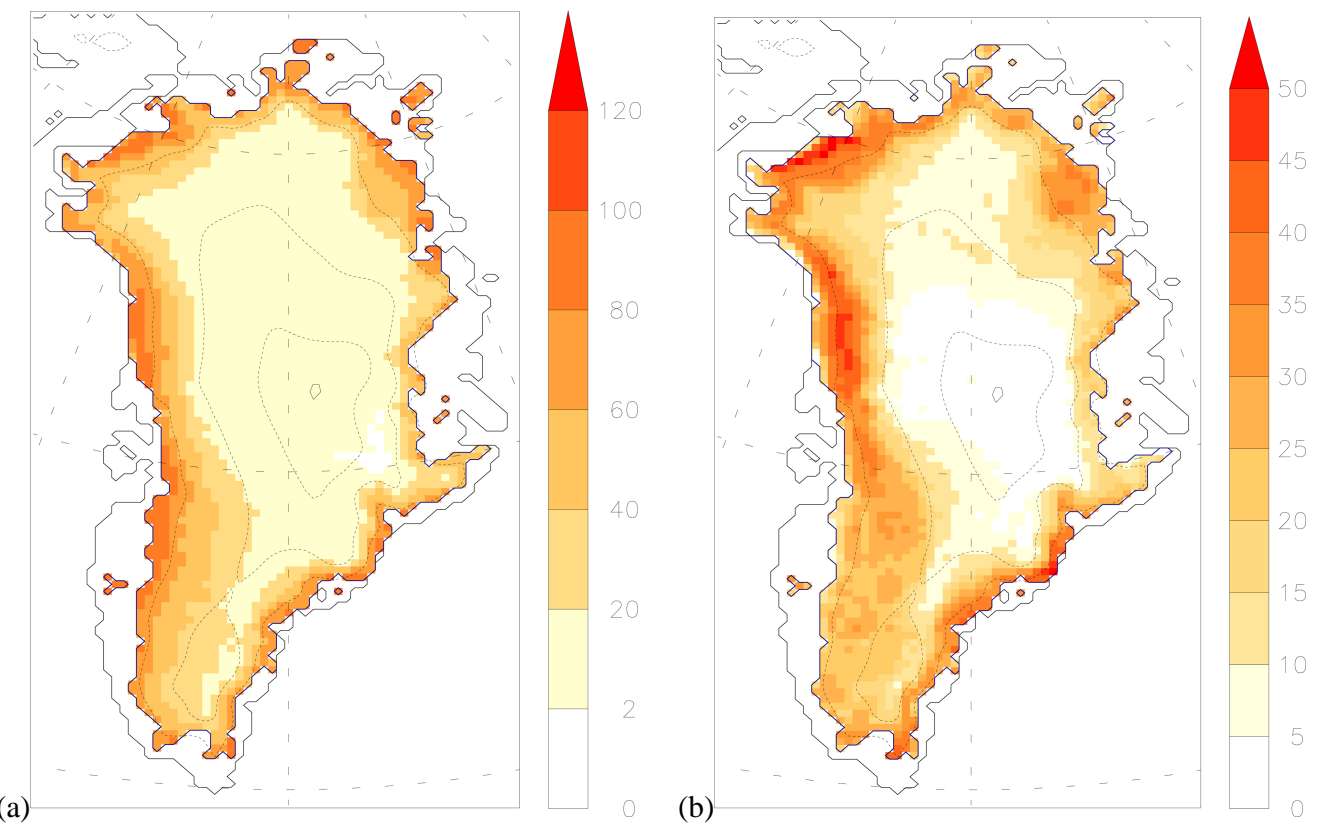

(a)

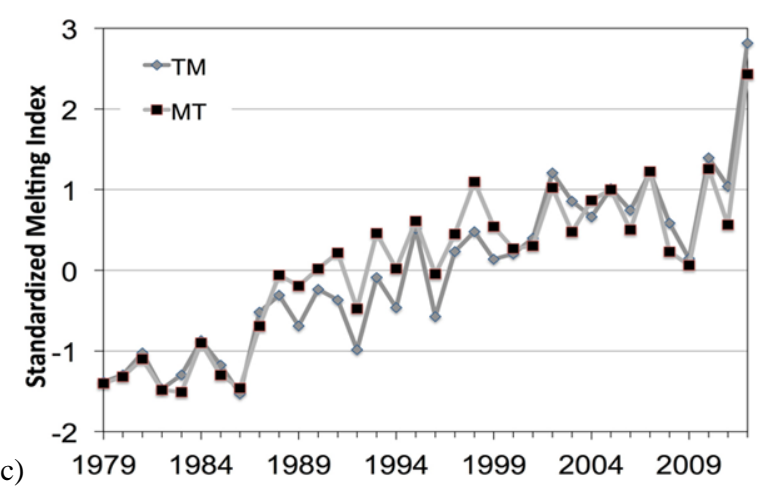

Fig. 4. (a) Melt duration (days) during June, July and August of 2012 from Mote and Anderson (1995) and (b) departure from the 1981-2010 average. (c) Standardized melting index (SMI) for the period 1979-2012 using the algorithm in Mote and Anderson (1995), denoted as TM, and in Tedesco (2009), denoted as MT.
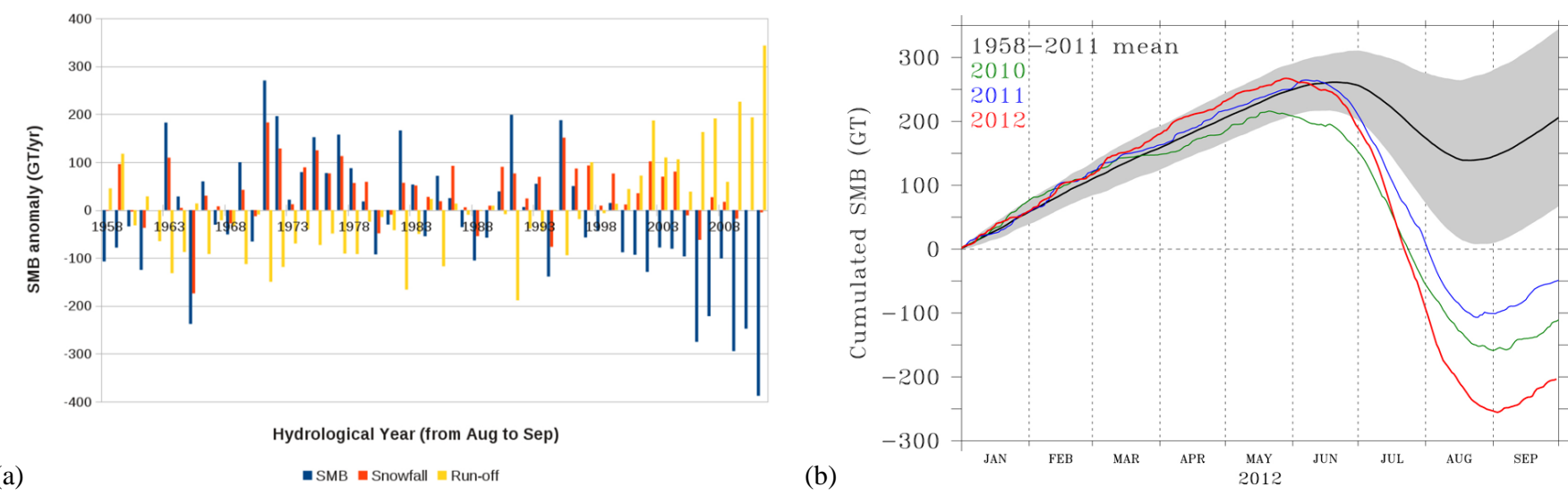

Fig. 5. (a) Bar plot of annual time series of the GrIS SMB, snowfall and runoff anomalies integrated over the hydrological year simulated by MAR, forced by ERA-40 over 1958-1978 and by ERA-INTERIM over 1979-2012. Units are Gt yr ${ }^{-1}$ and anomalies are given with respect to the 1958-2011 period. (b) Daily time series of the cumulative SMB ( $\mathrm{Gt} \mathrm{yr}^{-1}$ ) using 1 January as a reference for 2012 (dark blue), 2011 (light red) and 2010 (green) and for the 1958-2011 mean (50\% gray). 
Table 2. Melt duration (in days) for JJA 2012 and the 1981-2010 average (days) for a transect in West Greenland at approximately $72^{\circ} \mathrm{N}$ using the algorithm in Mote and Anderson (1995).

\begin{tabular}{rrlrrr}
\hline Latitude & Longitude & Elevation & 2012 & 1981-2010 & $\begin{array}{r}2012 \\
\text { departure }\end{array}$ \\
\hline 72.122 & -51.988 & 1685 & 64.0 & 25.6 & 38.5 \\
72.148 & -51.259 & 1739 & 56.0 & 14.7 & 41.3 \\
72.171 & -50.528 & 1961 & 43.0 & 9.0 & 33.9 \\
72.191 & -49.794 & 2080 & 33.0 & 6.6 & 26.4 \\
72.208 & -49.059 & 2220 & 21.0 & 5.7 & 15.3 \\
72.223 & -48.323 & 2325 & 15.0 & 4.7 & 10.3 \\
72.234 & -47.586 & 2460 & 10.0 & 3.1 & 6.9 \\
72.243 & -46.848 & 2547 & 7.0 & 2.0 & 5.0 \\
72.249 & -46.109 & 2641 & 6.0 & 1.2 & 4.8 \\
72.252 & -45.370 & 2714 & 5.0 & 0.7 & 4.2 \\
72.252 & -44.630 & 2770 & 5.0 & 0.8 & 4.1 \\
72.249 & -43.891 & 2846 & 5.0 & 0.6 & 4.4 \\
72.243 & -43.152 & 2887 & 4.0 & 0.0 & 4.0 \\
72.234 & -42.414 & 2969 & 4.0 & 0.0 & 4.0 \\
72.223 & -41.677 & 3001 & 5.0 & 0.0 & 5.0 \\
72.208 & -40.941 & 3064 & 4.0 & 0.0 & 4.0 \\
\hline
\end{tabular}

Table 3. Summer and annual mass changes from GRACE for the period 2003-2012.

\begin{tabular}{rrrr}
\hline Year & $\begin{array}{r}\text { Summer mass } \\
\text { change [Gt] }\end{array}$ & $\begin{array}{r}\text { Hydrological } \\
\text { year }\end{array}$ & $\begin{array}{r}\text { Annual mass } \\
\text { change [Gt] }\end{array}$ \\
\hline 2003 & $-382 \pm 122$ & $2003-2004$ & $-85 \pm 89$ \\
2004 & $-239 \pm 90$ & $2004-2005$ & $-356 \pm 91$ \\
2005 & $-419 \pm 92$ & $2005-2006$ & $-134 \pm 89$ \\
2006 & $-335 \pm 91$ & $2006-2007$ & $-325 \pm 91$ \\
2007 & $-454 \pm 93$ & $2007-2008$ & $-202 \pm 89$ \\
2008 & $-345 \pm 91$ & $2008-2009$ & $-218 \pm 89$ \\
2009 & $-383 \pm 91$ & $2009-2010$ & $-423 \pm 92$ \\
2010 & $-516 \pm 94$ & $2010-2011$ & $-319 \pm 91$ \\
2011 & $-435 \pm 122$ & $2011-2012$ & $-575 \pm 95$ \\
2012 & $-628 \pm 96$ & & \\
\hline
\end{tabular}

and the associated modeled runoff $\left(\sim 350 \mathrm{Gt} \mathrm{yr}^{-1}, 3.9\right.$ standard deviations above the 1958-2011 average). The simulated winter snowfall over 2011-2012 does not play a major role in setting the SMB record, because it is close to the 1958-2011 average (Fig. 6a). This is different from previous record melt summers $(2007,2008,2010,2011)$, when the low SMB anomaly was driven by substantial contributions from both high runoff anomalies and reduced winter accumulation (Tedesco et al., 2011). Figure 5b shows the daily time series of the cumulative SMB for 2010, 2011 and 2012, as well as for the 1958-2011 mean. The graph shows that the accumulated mass during winter in the case of 2010 was lower than that in 2011 and 2012 and highlights the relatively steep slope of the cumulative SMB starting around day 192 (10 July) 2012 (linear regression between day 192 and day 246 of $-7.69 \pm 0.2 \mathrm{Gt} \mathrm{yr}^{-1}$ day $^{-1}$,
$\left.R^{2}=0.99\right)$ with respect to $2011\left(-5.4 \pm 0.2 \mathrm{Gt} \mathrm{yr}^{-1} \mathrm{day}^{-1}\right)$ and $2010\left(-5.15 \pm 0.13 \mathrm{Gt} \mathrm{yr}^{-1} \mathrm{day}^{-1}\right)$. Figure $6 \mathrm{~b}$ shows the map of SMB anomalies for the 2011-2012 hydrological year simulated by MAR. SMB was below the average over the entire ice sheet with relatively low values in the ablation zones of the west and southeast regions. Simulated meltwater production for June through August (JJA, Fig. 6c) was also above the average over the entire ice sheet, with relatively high values (e.g., between 200 and $400 \mathrm{mmWE} \mathrm{yr}^{-1}$ ) at high elevations in South Greenland. Snowfall was considerably lower than normal in South Greenland for the JJA period of 2012 (Fig. 6d), as a result of abnormal anticyclonic conditions (discussed later). The relative lack of snowfall during summer (combined with sunnier than normal conditions resulting from the position of the anticyclone) was likely responsible for maintaining a low albedo during the entire summer in southern Greenland, further enhancing melting in this area. The reduced snowfall in the southeast is also due to the fact that a larger part of precipitation in the summer of 2012 fell as rain rather than as snow (not shown here), due to warmer conditions.

\subsection{Albedo}

MODIS results indicate that the ice-sheet-wide average albedo for JJA 2012 was the lowest since MODIS began collecting data with a value of 0.684 (vs. a value of 0.750 in year 2000), decreasing by $6.6 \%$ between 2000 and 2012 and with a linear fit suggesting a $-6.4 \pm 0.8 \%$ change. The degrading MODIS instrument sensitivity identified by Wang et al. (2012) introduces the possibility that the declining albedo trends may be erroneous. However, Box et al. (2012) discounted this problem through comparison of the MOD10A1 


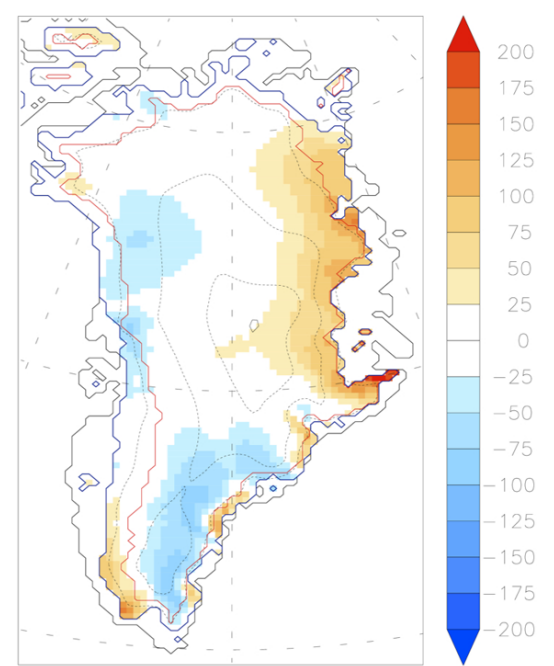

(a)

2011-2012 winter snowfall anomaly ( $\mathrm{mmWE}$ )

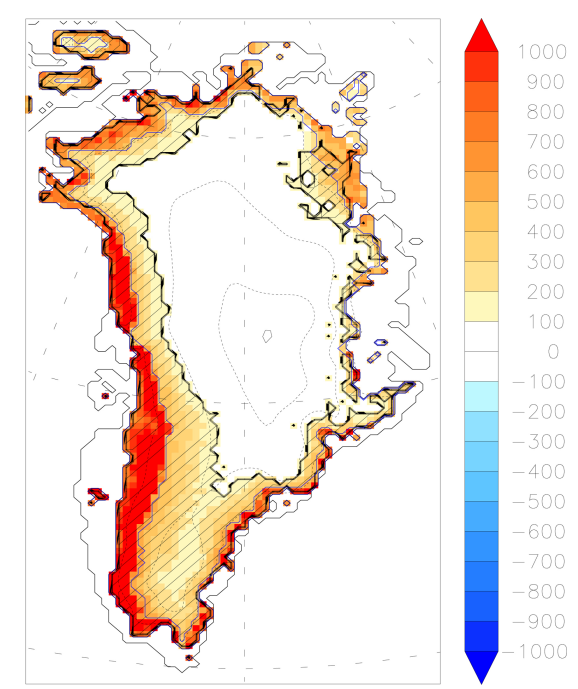

(c) 2012 JJA Meltwater anomaly (mmWE)$$
\text { 可 }
$$

(e)

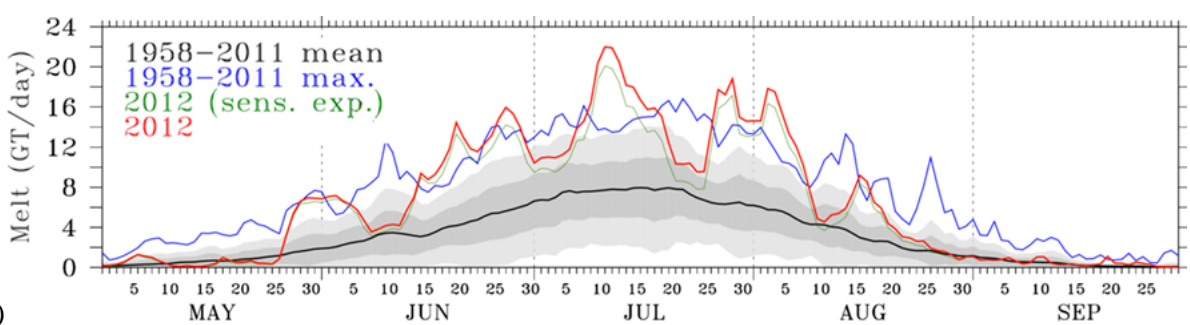

Fig. 6. (a) 2011-2012 winter accumulation anomaly (in mmWE) simulated by MAR with respect to 1958-2011. (b) 2012 SMB anomaly integrated over the hydrological year simulated by MAR with respect to 1958-2011. The 2011-2012 ELA (equilibrium line altitude) is plotted as a red line, and areas where the anomalies are at least twice the 1958-2011 standard deviation of MAR forced by ERA-INTERIM are hatched in black. (c) Same as (b) but for the JJA meltwater production. Only about 40-50\% of this meltwater reaches the ocean by runoff. The ELA is plotted in blue here. (d) Same as (b) but for the JJA snowfall. (e) Time series (in red) of the 2012 GrIS cumulative meltwater production simulated by MAR. The same simulation starting 1 May 2012 with the state of the snow pack from May 1997 is plotted in green for the purpose of a sensitivity analysis. The 1958-2011 mean simulated by MAR is plotted in black. The dark and light gray areas correspond to the 1958-2011 standard deviation and, respectively, 2 times the standard deviation of the GrIS MAR simulated values. Finally, the absolute daily maximum values over the considered period are plotted in blue. 
(a)

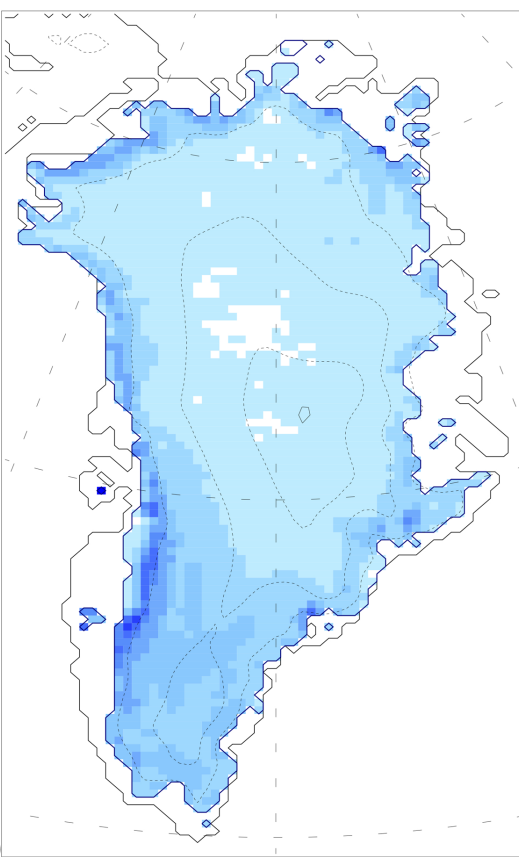

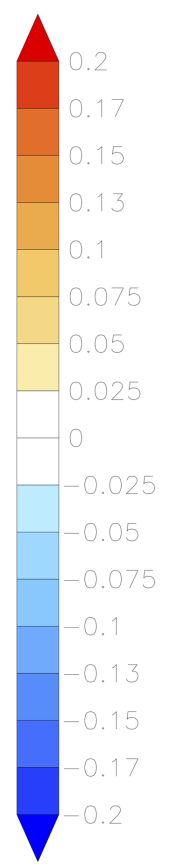

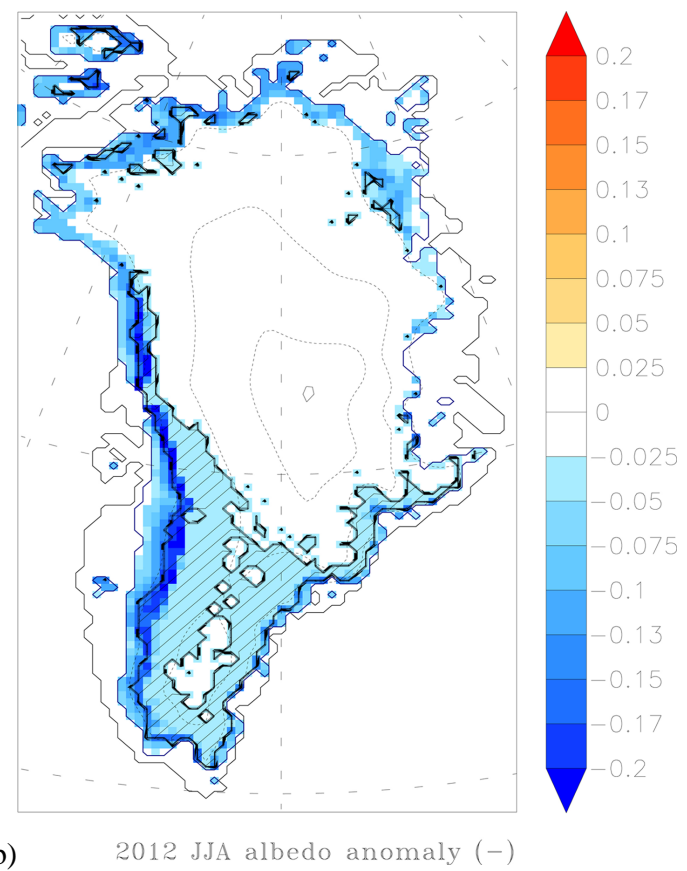

(b)

2012 JJA albedo anomaly (-)

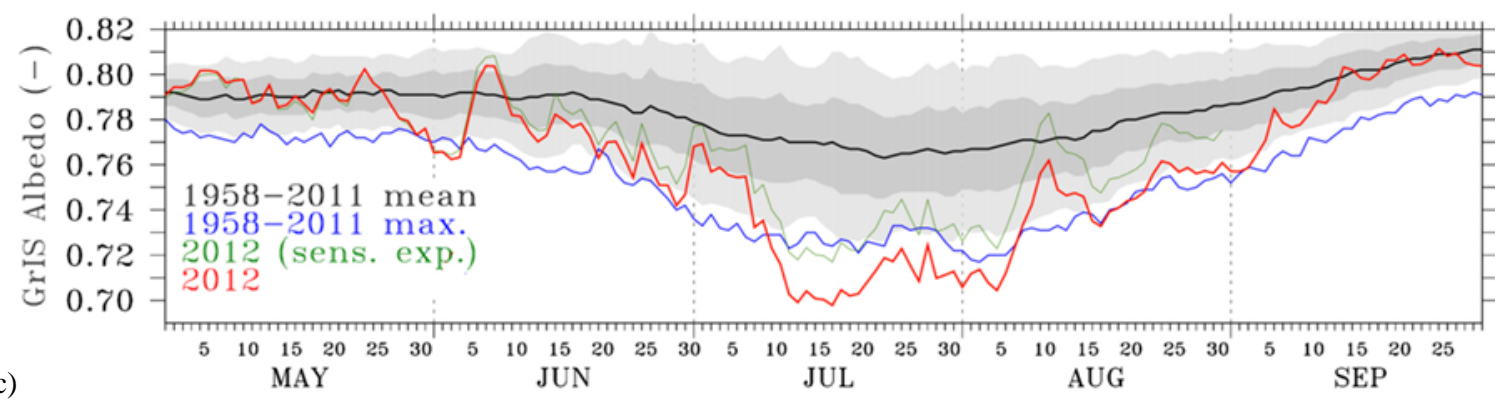

Fig. 7. (a) JJA MODIS albedo anomaly map following Box et al. (2012) for 2012 (using the 2000-2011 mean). MODIS data are re-projected onto MAR grid for graphical consistency purposes. (b) JJA MAR albedo anomaly map for 2012 (with respect to the 1958-2011 period). (c) Same as Fig. 6e but for albedo.

data with ground observations from sites distributed around the ice sheet and spanning $11 \mathrm{yr}$. Figure 7 shows the MODIS JJA 2012 albedo anomaly map with respect to the 2000-2011 mean. Figure $7 \mathrm{~b}$ shows the 2012 JJA albedo anomaly (with respect to the 1979-2011 baseline) obtained from MAR. Differences between Fig. 7a and $b$ can be attributed to the intrinsic differences between the two approaches, to the different baseline periods, and the spatial resolution of the two data sets. Nevertheless, both maps consistently indicate a decrease in albedo in 2012 with respect to previous years, especially along the southwest coast of Greenland. A preliminary analysis reveals an agreement between MAR and MODIS albedo of within 0.1 , with a slight positive MAR bias of $<0.1$ over the center of the ice sheet. The time series of the 2012 albedo simulated by MAR, together with the 1958-2011 mean and the absolute daily minimum albedo over the 1958-2011 period, are plotted in Fig 7c. MAR suggests that in 2012 the albedo over Greenland was below average, reaching new record low values in July and experiencing close-to-record values for most of August, with the exception of a short period at the beginning of August after a snowfall event.

\subsection{Total mass change from GRACE}

Results from GRACE reveal record 2012 GrIS mass loss, occurring in concert with the record observed and modeled surface temperature, albedo, and SMB anomalies indicated above. Figure 8 shows the cumulative mass anomalies (CMA) from GRACE through September 2012 over Greenland. The differences between the September and June CMA values and September through September are reported in Table 3. The fixed period for the hydrological year allows changes in mass over the same length of time to be compared, but can also result in changes from one season being attributed to an adjacent season. GRACE did not deliver a June value in 2003 or 2011. For those years, we used the May value instead, but we modified that value by adding the 


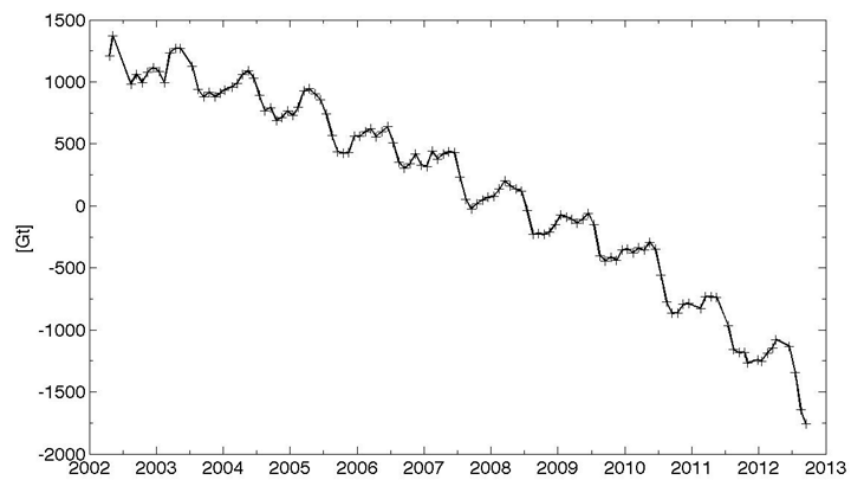

Fig. 8. Cumulative mass anomaly from GRACE updated through September 2012 (Gt).

average difference $(13 \pm 40 \mathrm{Gt}$, where \pm 40 is a $2 \sigma$ uncertainty estimate) between June and May for the $8 \mathrm{yr}$ (20042010, and 2012) in which both values were given. The error on the summer CMA results are computed by smoothing the monthly CMA values, subtracting that difference from the unsmoothed values, and computing the $2 \sigma$ scatter of the residuals. Fig. 8 and Table 3 show that when compared with all years during 2003-2012, 2012 set new records in terms of summertime and annual mass loss, with a mass change between June and August of $-628 \pm 96 \mathrm{Gt}$, approximately $2 \sigma$ below the 2003-2012 mean of $-414 \mathrm{Gt}$. The previous record was set in 2010, with a summer CMA value of $-516 \pm 94 \mathrm{Gt}$, which lays $\sim 0.8 \sigma$ below the mean. The summer mass change values have been growing steadily more negative over the GRACE period of observation. The trend of those values during $2003-2012$ is $-29 \pm 11 \mathrm{Gt} \mathrm{yr}^{-1}$. That trend reduces to $-20 \pm 13 \mathrm{Gt} \mathrm{yr}^{-1}$ if the summer of 2012 is excluded, which is a consequence of the fact that the 2012 summer mass loss was anomalously large, even after factoring in the steady increase in summer mass loss that has been occurring in recent years. In terms of annual loss (from mid-September to the successive mid-September), the 2012 loss was $-575 \pm 89 \mathrm{Gt}(\sim 2 \sigma$ below the mean), also setting a new record, exceeding the previous record set in 2010 of $-423 \pm 89 \mathrm{Gt}(\sim 0.7 \sigma$ below the mean). As shown by Sasgen et al. (2013), the 2012 mass balance anomaly is fully explained by anomalies in SMB and not likely in ice dynamics.

The uncertainties of the summer and yearly CMA results are computed by smoothing the monthly CMA values, subtracting that difference from the unsmoothed values, and computing the $2 \sigma$ scatter of the residuals. For the summer 2003 and 2011 results, we also add the uncertainty caused by using May values instead of June values. We add (in quadrature) this uncertainty, determined by the scatter in the time series, to the uncertainty caused by errors in the scaling factor (see above), to obtain the total uncertainty.

\section{Discussion}

The analysis of both modeling and satellite data indicates that the 2012 melt season started at the end of May with a warm event that was not enough to completely remove the 2011-2012 winter accumulation in the ablation area, with the modeled bare ice exposed area remaining relatively low (See Fig. 9). From mid-June to the beginning of July, there was a succession of warm episodes that increased melting and decreased albedo, but large areas in the ablation area still remained covered by the winter snowpack. Around 10 July, an anticyclonic ridge inducing one of the warmest conditions over the past $50 \mathrm{yr}$ contributed to the melting of most of the winter accumulation, exposing large bare ice regions in the ablation zone (seen as an increase in bare ice in Fig. 9). This event reduced the ice sheet albedo (Fig. 7) and induced the highest daily modeled meltwater production in the past 50 years (Fig. 6). A fourth melt event occurred at the end of July 2012, melting the fresh snow accumulated around 20 July and favoring the reduction in the albedo again. These two events have been recorded in the near-surface temperature at Summit (Nghiem et al., 2012). In general, the reduction of the albedo can be attributed to grain size metamorphism (e.g., constructive metamorphism reduces albedo through bounding of smaller grains) as well as bare ice exposure and ablation area melt water ponding. From Fig. 7 it is possible to observe that low negative albedo anomalies occur along the coastal areas corresponding to those regions where bare ice was exposed. In addition to the time series of the 2012 bare ice exposed area simulated by MAR, Fig. 9 shows the 1958-2011 mean and the absolute daily maximum bare ice area over 1958-2011. A comparison between Figs. 9 and 7 reveals a clear relationship between the MAR modeled albedo reduction for July and August and the simulated increase of the bare ice area exposed. This is the consequence of the increased melting on one side, but also of the reduced solid precipitation along southwest Greenland that characterized summer 2012 (as a consequence of the discussed anticyclonic, e.g., dry and warm, conditions).

In a synthetic sensitivity experiment, we tested the hypothesis that the simulated record of bare ice exposure might have been preconditioned by previous recent melting record years (e.g., 2010 and 2011). The removal of the seasonal accumulation from the previous years might indeed allow a premature exposure of bare ice, once the 2011-2012 winter accumulation melted in June 2012. We replaced MAR snowpack state variables for the top $10 \mathrm{~m}$ (density, temperature, grain size, etc.) on 1 May 2012 with those from 1 May 1997 (when previous summers, in particular 1996, were particularly wet and cold). The results of those simulations obtained using the May 1997 snowpack conditions are reported as green lines in Figs. 6e, 7c and 9. Figure 10 shows, as an example, the differences between the firn mean density and temperature in May 1997 (a, b) and May 2012 (c, d). The SMB rate in 1996 was one of the highest over the last two decades due to 


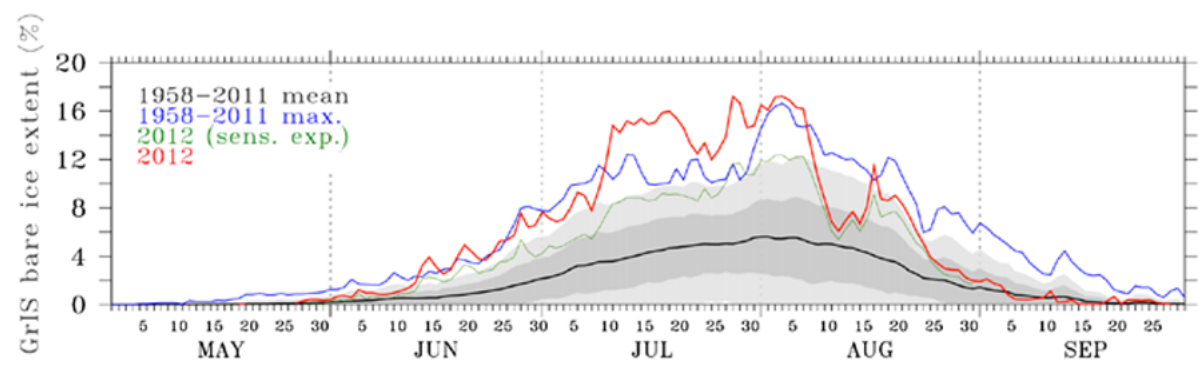

Fig. 9. Same as Fig. 6e but for the daily bare ice extent (where the snow density is higher than $900 \mathrm{~kg} \mathrm{~m}^{-3}$ ) in percentage of the GrIS area from MAR.

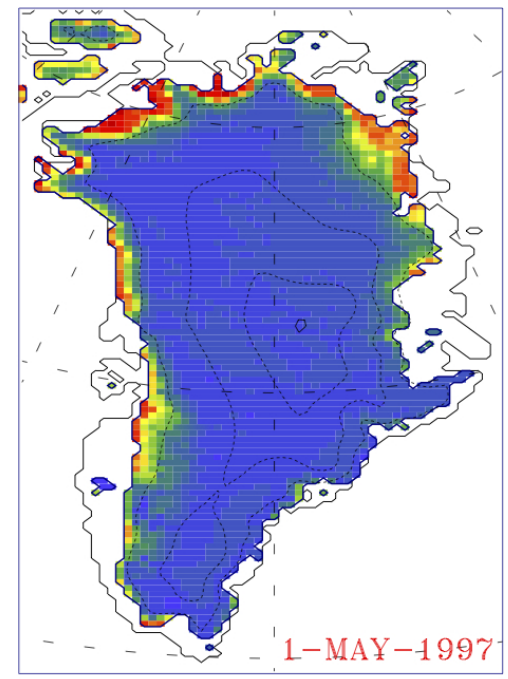

a) Snow Density $\left(\mathrm{kg} / \mathrm{m}^{3}\right)$

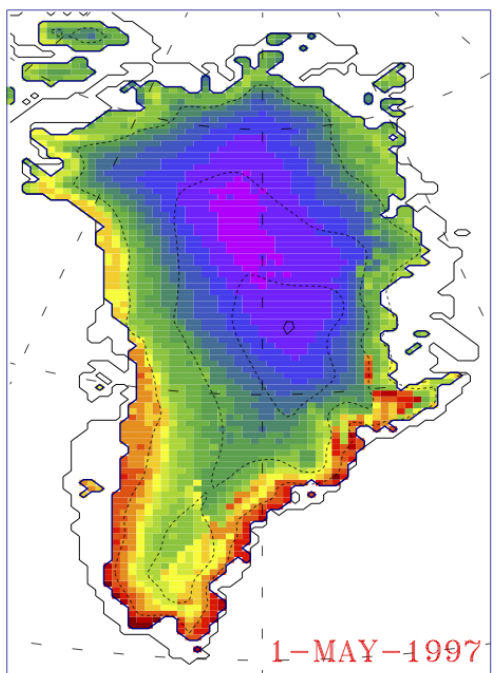

c) Snow Temperature $\left({ }^{\circ} \mathrm{C}\right)$

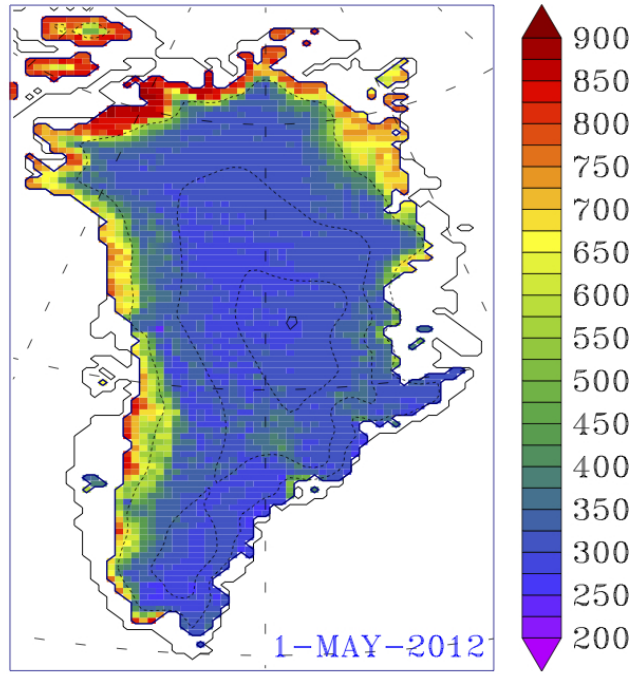

b) Snow Density $\left(\mathrm{kg} / \mathrm{m}^{3}\right)$
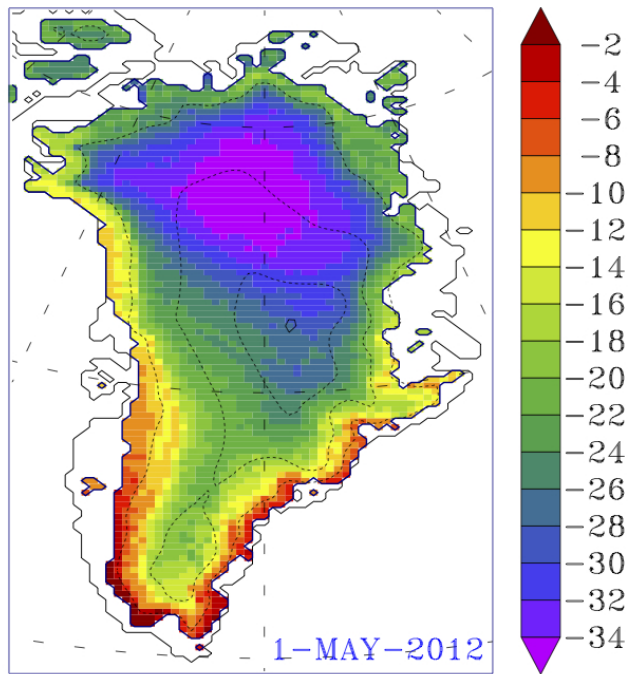

d) Snow Temperature $\left({ }^{\circ} \mathrm{C}\right)$

Fig. 10. Mean density $\left(\mathrm{kg} \mathrm{m}^{-3}\right.$, top figures) and mean snow temperature $\left({ }^{\circ} \mathrm{C}\right.$, bottom figures) within the first $2 \mathrm{~m}$ of snow simulated by MAR on 1 May 1997 (a), (c), and 1 May 2012 (b), (d). 


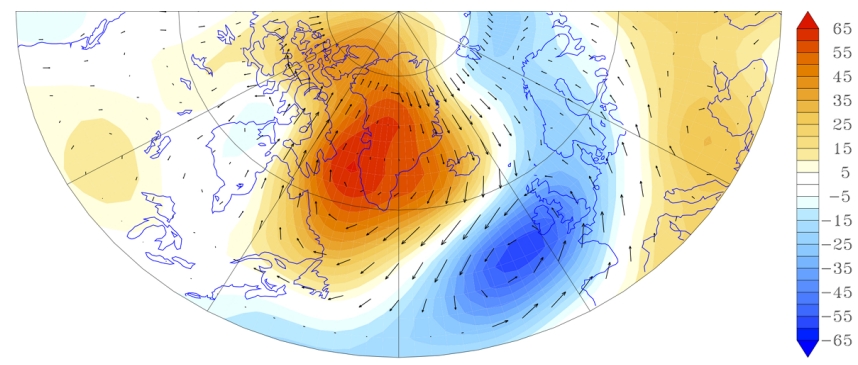

Fig. 11. $700 \mathrm{hmb}$ geopotential height $(\mathrm{m})$ and wind anomaly for June, July and August 2012 from the NCEP/NCAR Reanalysis data.

heavy snowfall and a cold summer. The bare ice extent during summer 2012 was larger than that in 1997 because it was inherited from the previous warm summers 2007-2011 when previous maxima of bare ice extent have been recorded (Box et al., 2012). The outputs indicate that with these new initial conditions for the snowpack (e.g., May 1997) the runoff rate (respectively, meltwater production) is reduced by $20 \%$ (by $10 \%)$ compared to the case when the original snow conditions from May 2012 were used. The decrease in runoff is greater because runoff of meltwater occurs mainly above the bare ice area. These results indicate that preconditioning of the snowpack from previous summers contributed in part to the record melt events of 2012.

Melting in 2012 was also considerably higher than normal along the western GrIS coast as a result of the enhanced warm southerly air advection associated with the abnormal persistence of anticyclonic circulation centered in South Greenland. Figure 11 shows an anticyclonic-like anomaly at $700 \mathrm{hPa}$ in the geopotential height (Z700) for JJA $2012 \mathrm{oc}-$ curring mainly over Greenland, which is not manifest over other regions of the Arctic, indicating a local pattern associated with the North Atlantic Oscillation (NAO). Following Fettweis et al. (2013), we classified $16 \%$ of the JJA days for 2012 as low pressure-like days, $55 \%$ as anticyclonic days and $28 \%$ as day with a general circulation over Greenland similar to the JJA climatological mean. On average over the period 1958-2011, the NCEP/NCAR Reanalysis data (Kalnay et al., 1996) shows that summer has, respectively, about $30 \pm 12 \%, 20 \pm 10 \%$ and $50 \pm 10 \%$ as low pressure-like days, anticyclonic and normal days. The identified frequency of the JJA days classified as anticyclonic during summer 2012 is the highest in 50 years (compared with 2007: $40 \%$; 2010: $33 \%$; 2011: $47 \%$ ). Figure 3 of Fettweis et al. (2013) shows the corresponding $500 \mathrm{hPa}$ geopotential height for the three types of circulation as well as the temperature anomalies at $700 \mathrm{hPa}$ induced by these circulation types. As shown in that figure, the JJA runoff amount simulated by MAR (forced by the ECMWF reanalysis) is highly correlated with the JJA mean temperature at $700 \mathrm{hPa}$ (T700) over Greenland. As for melt, T700 in summer 2012 was the highest in the previous $50 \mathrm{yr}$. Daily analogue JJA circulations

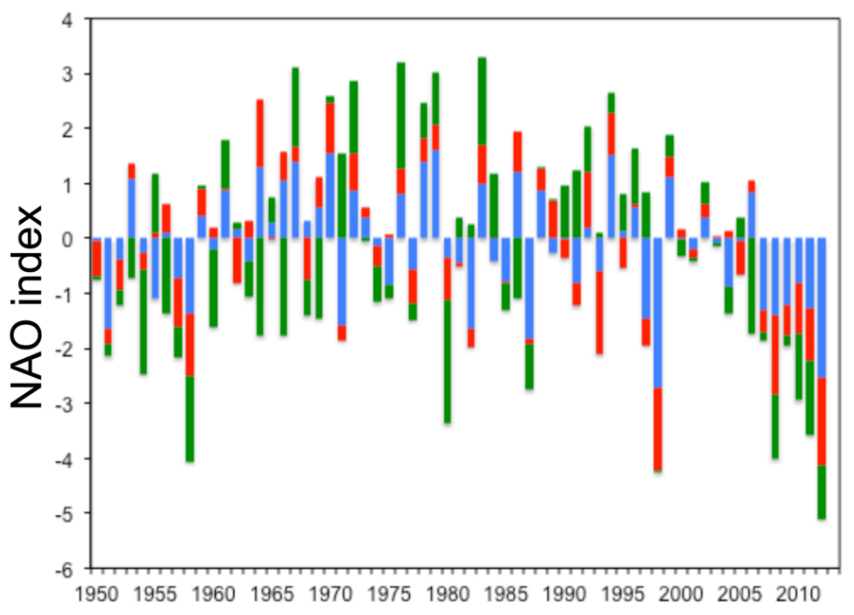

Fig. 12. North Atlantic Oscillation (NAO) index from NOAA Climate Prediction Center for June (blue), July (red), and August (green) for the period 1950-2012.

taken over 1961-1990 explain 55 $\pm 5 \%$ of the T700 anomaly in 2012. We refer to Fettweis et al. (2013) for more details about the analogue flows methodology and why 1961-1990 is chosen here as a baseline period. The analysis suggests that the abnormal anticyclonic conditions of summer 2012 explain at least $55 \%$ of this summer's T700 anomaly, and ultimately surface melt. The remaining $45 \%$ might be, therefore, attributed to a more general long-term warming occurring in the Arctic, as discussed by Fettweis et al. (2013).

The persistent anomalous ridging over Greenland was associated with persistent and anomalously negative North Atlantic Oscillation (NAO) index values. The NAO is the leading mode of low frequency variability in the cool season across the North Atlantic and is a large-scale dipole in atmospheric mass between the subtropical high and the polar low. Negative NAO values are associated with higher pressure and temperature over Greenland (Thompson and Wallace, 1998), surface melt extent (Mote , 1998; Tedesco et al., 2011), and melt/runoff (Hanna et al., 2013). Negative NAO values have been persistent during summers since 2006, but the summer of 2012 featured the most negative NAO for the period 19502012 (Fig. 12), based on the NOAA Climate Prediction Center NAO index values (Barnston and Livezey, 1987).

In addition to changes in the NAO, recent studies have pointed to persistent changes in early summer Arctic wind patterns for the past decade relative to previous decades, suggesting an enhancement of the so-called Arctic Dipole (AD), enhanced meridional flow across the Arctic for the period 2007-2012 and an increase in the Greenland Blocking Index (GBI; e.g., Overland et al., 2012). Should these largescale atmospheric changes persist, conditions responsible for SMB loss in recent years, including a reduction of snowfall, increasing liquid precipitation and runoff, will also persist, likely leading to increasingly negative values of the SMB. 


\section{Conclusions}

Relative to the beginning of the satellite record in 1979 , melt in Greenland is now starting about one month earlier at low elevations, with the area subject to melt increasing over 1979-2012 at a rate of between $\sim 20000$ and $22000 \mathrm{~km}^{2} \mathrm{yr}^{-1}$ (depending on the algorithm used). The amount and duration of melting at higher elevations has also been increasing, though at a slower rate. In this context, 2012 set new records in terms of melt extent (up to $\sim 97 \%$ of the entire ice sheet) and duration (up to about two months above the 1979-2012 mean for some areas), albedo, modeled bare ice exposure, SMB and runoff, and overall mass loss. Measured mean JJA ice-sheet-wide albedo was the lowest since the MODIS instrument began collecting measurements in 2000. The 2012 SMB anomaly (1958-2011 baseline) was $\sim-400 \mathrm{Gt} \mathrm{yr}^{-1}$ and the runoff anomaly was $350 \mathrm{Gt} \mathrm{yr}^{-1}$. The cumulative mass anomaly from GRACE indicates values of $\sim-628 \pm 96 \mathrm{Gt}$ for the summer period and $-575 \pm 94 \mathrm{Gt}$ for the 2011-2012 hydrological year. These anomalies exceed the record anomalies of 2010, when SMB and runoff records were also set.

Large-scale circulation patterns (e.g., NAO) and changes in local conditions (e.g., the snowpack heritage from previous summers) have acted in concert to increase SMB losses over previous years, through reduction of snowfall, increasing liquid precipitation and runoff. Premature and longer bare ice exposure was responsible, together with positive surface temperature anomalies, for the enhanced melting, which drove the SMB record in 2012. Anticyclonic conditions observed in recent years persisted in 2012, supporting more melting through the reduction of summer solid precipitation, persistent clear-sky conditions and the advection of warm air from the south, with the role played by the oceanic summer conditions around Greenland appearing to be negligible relative to the effects of the general circulation patterns (Hanna et al., 2012). Warmer temperatures lowered the albedo of snow covered areas likely through a combination of grain-size metamorphism, bare ice exposure, and meltwater ponding. Bare ice exposure was preconditioned by previous record melting years, through the removal of seasonal snowpack accumulated during the previous years. Should the trend continue for melting, there will be more bare ice exposed sooner and for longer periods, reducing surface albedo and leading to more absorbed solar energy.

Surface mass loss, together with losses from glacial flow, have been driving the recent records in terms of total mass loss identified through GRACE. Drainage basins along the southwest coast are projected to have the highest sensitivity of SMB to increasing temperatures during the 21 st century (Tedesco and Fettweis, 2012; Fettweis et al., 2013b). For these basins, the global temperature anomaly corresponding to a decrease of the SMB below the 1980-1999 average (when the ice sheet was near equilibrium) ranges between $+0.60^{\circ} \mathrm{C}$ and $+2.16^{\circ} \mathrm{C}$ (Tedesco and Fettweis, 2012). These are also the basins where positive feedbacks associated with bare ice exposure are projected to be the strongest. Because the CMIP5 general circulation models, used to predict future climate changes, do not project changes of the general circulation in summer over Greenland through this century (Belleflamme et al., 2012; Fettweis et al., 2013), their outputs do not account for the abnormal anticyclonic circulation resulting from negative NAO conditions that have been observed in recent years and that have been partially driving the enhanced melting and the observed records. Moreover, the MAR model and other RCMs, which have been used to project future SMB changes (e.g., Tedesco and Fettweis, 2012), are not currently coupled with ice sheet flow models, and, consequently, the impact of increased melting on ice dynamics is not accounted for. This suggests that the projected contribution to sea level rise under different warming scenarios might be underestimated (and the sensitivity to temperature changes might be higher) and points to the need for a synergic continuous monitoring of current changes using multiple tools (e.g., field observations, remote sensing, modeling) and interdisciplinary fields (e.g., a merging of glaciology, hydrology, atmospheric science) to improve future projections of the evolution of the GrIS.

Acknowledgements. M. T. and P. A. acknowledge the support of the NSF through grant no. 0909388 and of the NASA Cryospheric Sciences Program. B. W. is funded by a Marie Curie International Outgoing Fellowship within the 7th European Community Framework Programme (FP7-PEOPLE-2011-IOF-301260). J. W.'s contributions were partially supported by NASA grant NNX08AF02G and NNXI0AR66G, and by NASA's 'Making Earth Science Data Records for Use in Research Environments (MEaSUREs) Program'.

Edited by: M. Van den Broeke

\section{References}

A, G., Wahr, J., and Zhong, S.: Computations of the viscoelastic response of a 3-D compressible Earth to surface loading: an application to Glacial Isostatic Adjustment in Antarctica and Canada, Geophys. J. Int., in press, 2013.

Abdalati, W. and Steffen, K.: Snowmelt on the Greenland Ice Sheet as derived from passive microwave satellite data, J. Climate, 10, 165-175, 1997.

Barnston, A. G. and Livezey, R. E.: Classification, seasonality and persistence of low-frequency atmospheric circulation patterns, Mon. Wea. Rev., 115, 1083-1126, 1987.

Belleflamme, A., Fettweis, X., Lang, C., and Erpicum, M.: Current and future atmospheric circulation at $500 \mathrm{hPa}$ over Greenland simulated by CMIP3 and CMIP5 global models, Clim. Dynam., submitted, 2012.

Box, J. E., Fettweis, X., Stroeve, J. C., Tedesco, M., Hall, D. K., and Steffen, K.: Greenland ice sheet albedo feedback: thermodynamics and atmospheric drivers, The Cryosphere, 6, 821-839, doi:10.5194/tc-6-821-2012, 2012. 
Brun, E., David, P., Sudul, M., and Brunot, G.: A numerical model to simulate snow-cover stratigraphy for operational avalanche forecasting, J. Glaciol., 38, 13-22, 1992.

Catania, G. A., Neumann, T. A., and Price, S. F.: Characterizing englacial drainage in the ablation zone of the Greenland ice sheet, J. Glaciol., 54, 567-578, 2008.

Cheng, M. and Tapley, B. D.: Variations in the Earth's oblateness during the past 28 years, J. Geophys. Res., 109, B09402, doi:10.1029/2004JB003028, 2004.

Dee, D. P., Uppala, S. M., Simmons, A. J., Berrisford, P., Poli, P., Kobayashi, S., Andrae, U., Balmaseda, M. A., Balsamo, G., Bauer, P., Bechtold, P., Beljaars, A. C. M., van de Berg, L., Bidlot, J., Bormann, N., Delsol, C., Dragani, R., Fuentes, M., Geer, A. J., Haimberger, L., Healy, S. B., Hersbach, H., Hólm, E. V., Isaksen, L., Kållberg, P., Köhler, M., Matricardi, M., McNally, A. P., Monge-Sanz, B. M., Morcrette, J.-J., Park, B.-K., Peubey, C., de Rosnay, P., Tavolato, C., Thépaut, J.-N., and Vitart, F., The ERA-Interim reanalysis: configuration and performance of the data assimilation system, Q. J. R. Meteorol. Soc., 137, 553-597, doi:10.1002/qj.828, 2011.

De Ridder, K. and Gallée, H.: Land surface-induced regional climate change in southern Israel, J. Appl. Meteorol., 37, 14701485, 1998.

Fettweis, X.: Reconstruction of the 1979-2006 Greenland ice sheet surface mass balance using the regional climate model MAR, The Cryosphere, 1, 21-40, doi:10.5194/tc-1-21-2007, 2007.

Fettweis, X., Gallée, H., Lefebre, F., and van Ypersele, J.-P.: Greenland surface mass balance simulated by a regional climate model and comparison with satellite-derived data in 1990-1991, Clim. Dyn., 24, 623-640, doi:10.1007/s00382-005-0010-y, 2005.

Fettweis, X., Tedesco, M., van den Broeke, M., and Ettema, J.: Melting trends over the Greenland ice sheet (1958-2009) from spaceborne microwave data and regional climate models, The Cryosphere, 5, 359-375, 2011,

http://www.the-cryosphere-discuss.net/5/359/2011/.

Fettweis, X., Hanna, E., Lang, C., Belleflamme, A., Erpicum, M., and Gallée, H.: Brief communication "Important role of the midtropospheric atmospheric circulation in the recent surface melt increase over the Greenland ice sheet", , The Cryosphere, 7, 241248, doi:10.5194/tc-7-241-2013, 2013a.

Fettweis, X., Franco, B., Tedesco, M., van Angelen, J. H., Lenaerts, J. T. M., van den Broeke, M. R., and Galleee, H.: Estimating the Greenland ice sheet surface mass balance contribution to future sea level rise using the regional atmospheric climate model MAR, The Cryosphere, 7, 469-489, doi:10.5194/tc-7-469-2013, 2013 b.

Franco, B., Fettweis, X., Lang, C., and Erpicum, M.: Impact of spatial resolution on the modelling of the Greenland ice sheet surface mass balance between 1990-2010, using the regional climate model MAR, The Cryosphere, 6, 695-711, doi:10.5194/tc6-695-2012, 2012.

Franco, B., Fettweis, X., and Erpicum, M.: Future projections of the Greenland ice sheet energy balance driving the surface melt, developed using the regional climate MAR model, The Cryosphere, 7, 1-18, doi:10.5194/tc-7-1-2013, 2013.

Gallée, H. and Schayes, G.: Development of a three-dimensional meso- $\gamma$ primitive equation model: katabatic winds simulation in the area of Terra Nova Bay, Antarctica, Mon. Wea. Rev., 122, 671-685, 1994.
Gallée H., Peyaud V., and Goodwin, I.: Simulation of the net snow accumulation along the Wilkes Land transect, Antarctica, with a regional climate model. Annals of Glaciol., 41, 17-22, 2005.

Gloersen, P., Cavalieri, D. J., Chang, A. T. C., Wilheit, T. T., Campbell, W. J., Johannessen, O. M., Katsaros, K. B., Kunzi, K. F., Ross, D. B., Staelin, D., Windsor, E. P. L., Barath, F. T., Gudmandsen, P., Langham E., and Ramseier, R. O.: A summary of results from the first NIMBUS-7 SMMR observations, J. Geophys. Res., 89, 5335-5344, 1984.

Hall, D. K., Williams Jr., R. S., Luthcke, S. B., and Digirolamo, N. E.: Greenland ice sheet surface temperature, melt and mass loss: 2000-06, J. Glaciol., 54, 81-93, doi:10.3189/002214308784409170, 2008a.

Hall, D. K., Box, J. E., Casey, K., Hook, S. J., Shuman, C. A., and Steffen, K.: Comparison of satellite-derived and in-situ observations of ice and snow surface temperatures over Greenland, Rem. Sens. Environ., 112, 3739-3749, 2008b.

Hall, D. K., Riggs, G. A., and Salomonson, V. V.: MODIS/Terra Snow Cover Daily L3 Global $500 \mathrm{~m}$ Grid Version 4, January to March 2003, Digital media, updated daily, National Snow and Ice Data Center, Boulder, CO, USA, 2011.

Hanna, E., Huybrechts, P., Steffen, K., Cappelen, J., Huff, R., Shuman, C., Irvine-Fynn, T., Wise, S., and Griffiths, M.: Increased runoff from melt from the Greenland Ice Sheet: a response to global warming, J. Clim., 21, 331-341, doi:10.1175/2007JCL1964.1, 2008.

Hanna, E., Jones, J. M., Cappelen, J., Mernild, S. H., Wood, L., Steffen, K., and Huybrechts, P.: The influence of North Atlantic atmospheric and oceanic forcing effects on 1900-2010 Greenland summer climate and ice melt/runoff, Int. J. Climatol., 33, 862-880, doi:10.1002/joc.3475, 2012.

Hanna, E., Fettweis, X., Mernild, S. H., Cappelen, J., Ribergaard, M., Shuman, C., Steffen, K., Wood, L., and Mote, T.: Atmospheric and oceanic climate forcing of the exceptional Greenland Ice Sheet surface melt in summer, Int. J. Climatol., accepted, 2013.

Hollinger, J., Lo, R., Poe, G., Savage, R., and Pierce J.: Special Sensor Microwave/Imager User's Guide. Naval Research Laboratory Report, Washington, DC, 1987.

Kalnay, E., Kanamitsu, M., Kistler, R., Collins, W., Deaven, D., Gandin, L., Iredell, M., Saha, S., White, G., Woollen, J., Zhu, Y., Leetmaa, A., Reynolds, B., Chelliah, M., Ebisuzaki, W., Higgins, W., Janowiak, J., Mo, K., Ropelewski, C., Wang, J., Jenne, R., and Joseph, D.: The NCEP/NCAR 40 year reanalysis project, B. Am. Meteorol. Soc., 77, 437-471, 1996.

Koenig, L. S. and Hall, D. K.: Comparison of satellite, thermochron and air temperatures at Summit, Greenland, during the winter of 2008/09, J. Glaciol., 56, 735-741, 2010.

Lefebre, F., Gallée, H., van Ypersele, J.-P., and Greuell, W.: Modeling of snow and ice melt at ETH Camp (West Greenland): A study of surface albedo. J. Geophys. Res., 108, 4231, doi:10.1029/2001JD001160, 2003.

Lefebre, F., Fettweis, X., Galée, H., van Ypersele, J.-P., Marbaix, P., Greuell, W., and Calanca, P.: Evaluation of a high-resolution regional climate simulation over Greenland, Clim. Dyn., 25, 99116, doi:10.1007/s00382-005-0005-8, 2005.

Mernild, S. H., Mote, T., and Liston, G. R. : Greenland Ice Sheet surface melt extent and trends, 1960-2010, J. Glaciol., 57, 621627, 2011. 
Mote, T. L.: Mid-tropospheric circulation and surface melt on the Greenland ice sheet. Part I: Atmospheric teleconnections, Internat. J. Climatol., 18, 111-129, 1998.

Mote, T. L.: Greenland surface melt trends 1973-2007: Evidence of a large increase in 2007, Geophys. Res. Lett., 34, L22507, doi:10.1029/2007GL031976, 2007.

Mote, T. L. and Anderson, M.R.: Variations in melt on the Greenland ice sheet based on passive microwave measurements, J. Glaciol., 41, 51-60, 1995.

Nghiem, S. V., Hall, D. K., Mote, T. L., Tedesco, M., Albert, M. R., Keegan, K., Shuman, C. A., DiGirolamo, N. E., and Neuman, G.: The Extreme Melt across the Greenland Ice Sheet in 2012, Geophys. Res. Lett., 39, L20502, doi:10.1029/2012GL053611, 2012.

Overland, J. E., Francis, J. A., Hanna E., and Wang M.: The recent shift in early summer Arctic atmospheric circulation, Geophys. Res. Lett., 39, L19804, doi:10.1029/2012GL053268, 2012

Peltier, W. R.: Global glacial isostasy and the surface of the ice-age earth: The ice-5G (VM2) model and GRACE, Ann. Rev. Earth Planet. Sci., 32, 111-149, doi:10.1146/annurev.earth.32.082503.144359, 2004.

Rae, J. G. L., Aalgeirsdóttir, G., Edwards, T. L., Fettweis, X., Gregory, J. M., Hewitt, H. T., Lowe, J. A., Lucas-Picher, P., Mottram, R. H., Payne, A. J., Ridley, J. K., Shannon, S. R., van de Berg, W. J., van de Wal, R. S. W., and van den Broeke, M. R.: Greenland ice sheet surface mass balance: evaluating simulations and making projections with regional climate models, The Cryosphere, 6 , 1275-1294, doi:10.5194/tc-6-1275-2012, 2012.

Rignot E., Velicogna, I., van den Broeke, M. R., Monaghan, A., and Lenaerts, J.: Acceleration of the contribution of the Greenland and Antarctic ice sheets to sea level rise, Geophys. Res. Lett., 38, L05503, doi:10.1029/2011GL046583, 2011.

Sasgen, I., Wouters, B., Fettweis, X., Dahle, C., and Vernon, C.: The centenary Greenland melt cycle 2012 recovered with satellite gravimetry, PNAS, submitted, 2013.

Steffen, K., Box, J. E., and Abdalati W.: Greenland climate network: GCNet, US Army Cold Regions Reattach and Engineering (CRREL), CRREL Special Report, 98-103, 1996.

Steffen, K., Nghiem, S. V., Huff, R., and Neumann, G.: The melt anomaly of 2002 on the Greenland Ice Sheet from active and passive microwave satellite observations, Geophys. Res. Lett., 31, L20402, doi:10.1029/2004GL020444, 2004.

Stroeve, J. C., Box, J. E., and Haran, T.: Evaluation of the MODIS (MOD10A1) daily snow albedo product over the Greenland ice sheet, Remote Sens. Environ., 105, 155-171, 2006.

Swenson, S., Chambers, D., and Wahr, J.: Estimating Geocenter Variations from a Combination of GRACE and Ocean Model Output. J. Geophys. Res., 113, B08410, doi:10.1029/2007JB005338, 2008.

Tapley B. D., Bettadpur S., Ries J. C., Thompson, P. F., and Watkins, M. M.: GRACE measurements of mass variability in the Earth system, Science, 305, 503-505, doi:10.1126/science.1099192, 2004.

Tedesco, M.: Snowmelt detection over the Greenland ice sheet from SSM/I brightness temperature daily variations, Geophys. Geophys. Research Res. LettersLett., 34, L02504, doi:10.1029/2006GL028466, 2007.

Tedesco, M.: Assessment and development of snowmelt retrieval algorithms over Antarctica from K-band spaceborne brightness temperature (1979-2008), Remote Sens. Environiron., 113, 979997, 2009.

Tedesco, M., Serreze, M., and Fettweis, X.: Diagnosing the extreme surface melt event over southwestern Greenland in 2007, The Cryosphere, 2, 159-166, doi:10.5194/tc-2-159-2008, 2008.

Tedesco, M., Fettweis, X., van den Broeke, M. R., van de Wal, R. S. W., Smeets, C. J. P. P., van de Berg, W. J., Serreze, M. C., and Box, J. E.: Env. Res. Lett., 6, 014005, 2011.

Tedesco, M., Lüthje, M., Steffen, K., Steiner, N., Fettweis, X., Willis, I., Bayou, N., and Banwell, A.: Measurement and modeling of ablation of the bottom of supraglacial lakes in western Greenland, Geophys. Res. Lett., 39, L02502, 2012a.

Tedesco, M. and Fettweis, X.: 21st century projections of surface mass balance changes for major drainage systems of the Greenland ice sheet, Environ. Res. Lett., 7, 045405, doi:10.1088/17489326/7/4/045405, 2012.

Thompson, D. W. J. and Wallace, J. M.: The Arctic Oscillation signature in the wintertime geopotential height and temperature fields, Geophys. Res. Lett., 25, 1297-1300, doi:10.1029/98GL00950, 1998.

van den Broeke, M., Bamber, J., Ettema, J., Rignot, E., Schrama, E., van de Berg, W. J., van Meijgaard, E., Velicogna, I., and Wouters, B.: Partitioning recent Greenland mass loss, Science, 326, 984986, doi:10.1126/science.1178176, 2009.

van der Veen, C. J.: Fracture propagation as means of rapidly transferring surface meltwater to the base of glaciers, Geophys. Res. Lett., 34, L01501, doi:10.1029/2006GL028385, 2007.

van de Wal, R. S. W., Boot, W., Smeets, C. J. P. P., Snellen, H., van den Broeke, M. R., and Oerlemans, J.: Twenty-one years of mass balance observations along the K-transect, West Greenland, Earth Syst. Sci. Data, 4, 31-35, doi:10.5194/essd-4-312012, 2012.

Velicogna, I. and Wahr, J.: Significant acceleration of Greenland ice mass loss in spring 2004, Nature, 443, 329-331, doi:10.1038/nature05168, 2006.

Vernon, C. L., Bamber, J. L., Box, J. E., van den Broeke, M. R., Fettweis, X., Hanna, E., and Huybrechts, P.: Surface mass balance model intercomparison for the Greenland ice sheet, The Cryosphere Discuss., 6, 3999-4036, doi:10.5194/tcd-6-39992012, 2012.

Wahr, J., S. Swenson, V. Zlotnicki, and I. Velicogna: TimeVariable Gravity From GRACE: First Results, 31, L11501, doi:10.1029/2004GL019779, 2004.

Wan, Z. M.: New refinements and validation of the MODIS LandSurface Temperature/Emissivity products, Remote Sens. Environ., 112, 59-74, doi:10.1016/j.rse.2006.06.026, 2008.

Wan, Z. M., Zhang, Y., Zhang, Q., and Li, Z.-L.: Validation of the land-surface temperature products retrieved from Terra Moderate Resolution Imaging Spectroradiometer data, Remote Sens. Environ., 83, 163-180, 2002.

Wang, D., Morton, D., Masek, J., Wu, A., Nagol, J., Xiong, X., Levy, R., Vermote, E., and Wolfe, R.: Impact of sensor degradation on the MODIS NDVI time series, Remote Sens. Environ., 119, 55-61, 2012.

Weertman, J.: Can a water-filled crevasse reach the bottom surface of a glacier?, Int. Assoc. Sci. Hydrol. Publ., 95, 139-145, 1973.

Zwally, H. J. and Fiegles, S.: Extent and duration of Antarctic surface melting, J. Glaciol., 40, 463-476, 1994. 